\title{
Public Utility Bill Inserts, Political Speech, and the First Amendment: A Constitutionally Mandated Right to Reply
}

Recent United States Suprenie Court cases, while recognizing the potential dangers of corporate advocacy, ${ }^{1}$ have upheld corporations' rights to engage in political expression through both political contributions and direct advocacy, and have struck down laws aimed at restricting such speech activity. ${ }^{2}$ In 1980, the Court expanded this corporate speech right by holding that a regulatory agency could not prevent a state-regulated public utility from using its billing envelopes to advocate nuclear power even though the coinpany's monopoly status was conferred by the state and the corporation had a duty to operate in the public interest. ${ }^{3}$

Given that state-created monopolies can now employ this unique and pervasive forum for political speech, the Court could have determined that these companies must be required to afford groups with opposing views a right to reply to the utilities' political statenents. The Court, however, explicitly chose not to decide this issue. ${ }^{4}$

This Cominent addresses this unanswered question and argues that the first amendment requires utilities to afford opposing groups a right to reply ${ }^{5} \mathrm{i}$ the billing envelopes whenever a utility uses the envelopes to voice its opinion on controversial issues. Part I discusses the Supreme Court's decisions regarding the rights of corporations to en-

1. See, e.g., First Nat'l Bank of Boston v. Bellotti, 435 U.S. 765, 789-90 (1978); id. at 809-12 (White, J., dissenting).

2. Id. at 795; Buckley v. Valeo, 424 U.S. 1 (1976) (per curiam).

3. Consolidated Edison Co. v. Public Serv. Comm'n, 447 U.S. 530 (1980).

4. Id. at 543 .

5. A right to reply should be distinguished at the outset from a right of access. Access rights allow speakers to employ forums that the state lias sought to close off to everyone. See, e.g., Edwards v. South Carolina, 372 U.S. 229 (1963) (state capital grounds cannot be closed to the exercise of first amendinent rights). A right to reply is a narrower, more restricted concept. One or more speakers have already employed a forum, presenting a particular viewpoint on a given topic. The party claiming a right to reply aspires only to present an alternative viewpoint on the same topic in that forum. See, e.g., Madison School Dist. v. Wisconsin Employment Relations Coinm'n, 429 U.S. 167 (1976) (teacher cannot be banned from using a school board meeting as a forum for expressing views contrary to those expressed by others in that forum). The two concepts are, however, closely related. Once a party is granted access to a public forum, under equal protection other views may not be excluded on the basis of content. E.g., Police Dept. of Chicago v. Mosley, 408 U.S. 92 (1972). 
gage in political speech. Part II analyzes the first aunendment policies that are implicated when monopolies become participants in the "marketplace of ideas." Part III outlines the state action requirement and concludes that utility companies' political speech in billing envelopes is infused with state action, thus subjectimg the companies' inailing practices to the restrictions of the first amendment. Part IV argues that the public forum doctrine of the first ainendment requires recognition of a right to reply. Fimally, Part V suggests some inethods for implementing a right to reply.

I

Corporate Political Speech: OPENING UP PANDORA's BOX

\section{A. The Development of First Amendment Protection for Corporate Political Speech}

Speech by commercial enterprises las not always been protected by the first amendment. ${ }^{6}$ In the last decade, lowever, the Court has come to recognize that the "relationship of speech to the marketplace of products or of services does not inake it valueless in the marketplace of ideas."7 As a result, the Court has extended first amendnient protection to commercial speech. ${ }^{8}$ Most recently, the Court has addressed the constitutionality of statutes and regulations designed to limit the ability of corporate enterprises to engage in political debate. These statutes stein from fears that corporations, with large agglomerations of wealth-owned by masses of people, yet controlled by a few-have the potential to jeopardize deinocratic principles, by virtue of large expenditures of funds which could unduly mfluence pubhic opinion by drowning out opposing views. ${ }^{9}$ In a series of cases decided im the late 1970's

6. Valentine v. Chrestensen, 316 U.S. 52 (1942), set forth the commercial speech exception. More recent cases extending the commercial speech exception include Pittsburgh Press Co. v. Pittsburgh Comm'n on Human Relations, 413 U.S. 376 (1973); Breard v. Alexandria, 341 U.S. 622 (1951). See generally Roberts, Toward a General Theory of Commercial Speech and the First Amendment, 40 OHiо ST. L.J. 115 (1979); Heller, The End of the "Commercial Speech" Exception-Good Riddance or More Headaches for the Courts?, 67 KY. L.J. 927 (1978-79).

7. Bigelow v. Virginia, 421 U.S. 809, 826 (1975).

8. See Bates v. State Bar of Ariz., 433 U.S. 350 (1977) (advertisements of prices of routine legal services protected under the first amendment); Limmark Assocs. v. Township of Willingboro, 431 U.S. 85 (1977) (ordinance banning display of "for sale" or "sold" signs in front of residential property to reduce property turnover violated first amendment); Virginia State Bd. of Pharmacy v. Virginia Citizen's Consumer Council, 425 U.S. 748 (1976) (statute banning advertising of prescription drugs declared void); Bigelow v. Virginia, 421 U.S. 809 (1975) (statute making abortion advertisement illegal held unconstitutional).

9. See First Nat'l Bank of Boston v. Bellotti, 435 U.S. 765, 809 (1978) (White, J., dissenting):

The interest of Massachusetts and the inany other States which have restricted corporate pohtical activity is . . . one of ... preventing institutions which have been permitted to 
and early 1980's, the Court has held these statutes unconstitutional and has recognized that a corporation's first amendment rights include the right to engage $\mathrm{m}$ political speech even if that speecl is unrelated to the corporation's busimess activities.

The first case in this series was Buckley v. Valeo, ${ }^{10}$ where the Court considered constitutional challenges to statutes limiting contributions and expenditures for election campaigns. ${ }^{11}$ The Court's per curiam opinion noted that both political contributions and expenditures "iniplicate fundamental First Amendment imterests,"12 and lield that limitations on contributions are constitutional, while limitations on expenditures are not. The Court reasoned that limitations on expenditures iniposed direct and substantial restrictions on the ability of candidates to engage im protected political expression, and that the government's interest in equalizing the financial resources of candidates competing for public office is not a sufficient justification for sucl a restriction. ${ }^{13}$ Contribution and disclosure provisions, however, entail only a marginal restriction on the contributor's ability to engage in free commumication, ${ }^{14}$ and they serve a basic governmental interest in safeguarding the integrity of the electoral process by reducing the existence, or appearance of, improper influence stemming froin the dependence of candidates on large campaign contributions. ${ }^{15}$

In First National Bank of Boston v. Bellotti, ${ }^{16}$ the Supreme Court addressed for the first time the issue of whether a corporation's first amendment rights are distmct from those of an individual, or whetler a corporation's speech could be restricted by virtue of its source. In Bellotti, a group of national banking associations and business corporations wanted to spend money to publicize their views opposing a referendum proposal that would amend the Massachusetts Constitution to enable the legislature to enact a graduated income tax. They brought an action challenging the constitutionahty of a Massachusetts criminal statute that prohibited specified busmess corporations froin making contributions or expenditures "for the purpose of . . . influencing or affecting the vote on any question subunitted to the voters, other than one materially affecting any of the property, busmess or assets of

amass wealth as a result of special advantages extended by the State for certain economic purposes from using that wealth to acquire an unfair advantage in the political process, especially where, as here, the issue involved has no material connection with the business of the corporation. The State need not permit its own creation to consume it.

10. 424 U.S. 1 (1976) (per curiam).

11. Id. at $6-7$.

12. Id. at 23 .

13. Id. at 39-59.

14. Id. at 20-21.

15. Id. at $23-38,58$.

16. 435 U.S. 765 (1978). 
the corporation." 17 The Supreme Judicial Court of Massachusetts, focusing on the question of whether and to what extent a corporation has first amendinent rights, upheld the statute. ${ }^{18}$

The Supreme Court reversed ${ }^{19}$ and noted that the first amendment does not merely protect the rights of the speaker, ${ }^{20}$ but also ensures the free flow of vital information. ${ }^{21}$ The Court stated that the worth of speech does not depend on its source and that there is no justification for concluding that speech loses its first amendment protection by virtue of the fact that it flows from a corporation. ${ }^{22}$

After Bellotti affirmed the constitutional right of a corporation to engage in political debate, the next question was whether state-regulated monopoly corporations, with their unique position of power and their obhigation to operate $n 1$ the public interest, ${ }^{23}$ would be entitled to engage in political debate under the protection of the first annendment. This issue came before the Supreme Court only two years later in Consolidated Edison Co. v. Public Service Commission. ${ }^{24}$

\section{B. The Con Ed Decision: Expanding First Amendment Protection for a Monopoly's Political Speech}

The Con Ed case arose after Consolidated Edison Corporation, New York's electrical utility, placed a pro-nuclear power statement in the January 1976 billing envelopes that were sent to each of the utility's ratepayers. ${ }^{25}$ The bill insert contained Consolidated Edison's views on the "benefits of nuclear power," maintaining that these benefits "far outweigh any potential risk" and that nuclear power plants are safe, economical and clean. The utility also contended that increased use of nuclear energy would further this country's goal of independence froin

17. Id. at 768 .

18. See First Nat'l Bank of Boston v. Bellotti, 371 Mass. 773, 783, 359 N.E.2d 1262, 1269 (1977), rev'd, 435 U.S. 765 (1978).

19. Chief Justice Burger wrote a separate concurring opinion, 435 U.S. at 795-802, Justice White filed a dissenting opinion in which Justices Brennan and Marshall joined, $i d$. at 802-22, and Justice Rehnquist filed a separate dissent, $i d$. at 822-28.

20. 435 U.S. at 776.

21. "[T]he First Amendinent goes beyond protection of the press and the self-expression of individuals to prohibit government from limiting the stock of information froin which inembers of the public may draw." Id. at 783.

22. Id. at 784.

23. See Munn v. Illinois, 94 U.S. 113, 130-32 (1876); infra note 47.

24. 447 U.S. 530 (1980), noted at 1981 WIS. L. REv. 399 . On the same day, the Court decided a companion case, Central Hudson Gas \& Elec. Corp. v. Public Serv. Comm'n, 447 U.S. 557 (1980), which addressed the question of whether a state regulatory coinmission could ban a utility's use of promotional advertising, on the basis that the state had an interest in conserving energy and insuring fair and efficient rates for electricity. Although both cases deal with utility compames' first amendment rights, Central Hudson is not immediately relevant to this Comment.

25. Consolidated Edison's statement was entitled "Independence Is Still a Goal, and Nuclear Power is Needed to Win the Battle." 447 U.S. at 532. 
foreign energy sources. ${ }^{26}$ Subsequently, the National Resources Defense Council, Inc. (NRDC) requested that Consolidated Edison enclose a rebuttal prepared by NRDC in its next billing envelope. Consohidated Edison refused and NRDC asked the New York Public Service Commission to open Consolidated Edison's billing envelopes to opposing views on controversial issues of public importance.

Almost a year later, the Public Service Commission denied NRDC's request, and, instead, announced a rule prohibiting “utilities from using bill inserts to discuss pohtical matters, including the desirability of the future development of nuclear power.,27 The commission did not bar utilities from sending bill inserts which discussed topics which were not "controversial issues of public policy."28

After the New York Court of Appeals affirmed the commission's ruling ${ }^{29}$ Consolidated Edison appealed to the United States Supreine Court. The Court, relying on Bellotti, held that the commission's ban on bill inserts carrying a utility's political message was an unconstitutional infringement of protected speech. ${ }^{30}$ The Court said that under Bellotti a state cannot confine corporate speech to specified issues. Rather, "[t]he inherent worth of the speech in terins of its capacity for informing the public does not depend upon the identity of its source, whether corporation, association, union, or individual."31 Since the commission's restriction was not content neutral, the action was not a vahd time, place, or inamer restriction.

Although the commission had argued that its order was a constitutional subject inatter regulation because it applied to all discussion of nuclear power in bill inserts, the Court was unpersuaded by this argument, noting that '[ $[$ ] $]$ he First Amendinent's hostility to content-based regulation extends not only to restrictions on particular viewpoints, but also to prohibition of pubhic discussion of an entire topic."32 While the New York Court of Appeals had relied on Greer v. Spock ${ }^{33}$ and Lehman v. City of Shaker Heights, ${ }^{34}$ which illustrate the narrow circuinstances under which governmental regulation based on subject matter

26. Id.

27. Id.

28. Id. at 533 .

29. 47 N.Y.2d 94, 390 N.E.2d 749, 417 N.Y.S.2d 30 (1979), rev'd, 447 U.S. 530 (1980). For discussions of the New York Court of Appeals decision, see Note, Regulation of Advertising and Promotional Practices of Public Utilities Under the First Amendment, 8 FORDHAM URB. L.J. 373 (1980); Note, Restrictions on Electric Utility Advertising, 78 MicH. L. REv. 433 (1980).

30. 447 U.S. at 544.

31. Id. at 533 (citing Bellotti, 435 U.S. at 777).

32. Id. at 537 .

33. 424 U.S. 828 (1976) (military base may prohibit political campaigning and distribution of literature).

34. 418 U.S. 298 (1974) (city transit system may ban political advertising). 
has been approved, the Supreme Court distinguished those two cases. Both Greer and Lehman imvolved instances where private parties asserted a right of access to public facilities. Consolidated Edison did not seek to utilize public property to promulgate its views, but desired to use only its own billing envelopes. Since the commission could not rely on precedent that "rests on the special interests of a government im overseeing the use of its property,"35 its restriction did not fall within the exception and, thus, did not constitute a permissible subject-matter regulation. ${ }^{36}$

The Court also rejected the argument that the ban was a narrowly drawn prohibition that served compelling state interests. The commission had argued that its prohibition was necessary to avoid forcing Consolidated Edison's views on a captive audience, to allocate limited resources in the pubhic interest, and to ensure that ratepayers do not subsidize the cost of bill inserts. The Court rejected the first argument simce the first amendment permits the government to prohibit speech as intrusive only if the "captive" audience cannot avoid the objectionable speech. Customers of Consolidated Edison could escape the objectionable material, the Court mamtained, simply by depositing the bill insert in the wastebasket. ${ }^{37}$

In promoting its limited resources argument, the commission relied on Red Lion Broadcasting Co. v. FCC, ${ }^{38}$ where the Court recognized extensive governmental authority over speech in order to regulate radio and television broadcast frequencies. The Court distinguislied Red Lion on the basis that a broadcaster communicates through the use of a scarce, publicly owned resource, which may not be einployed without a license, while anyone can correspond to private lomes through the mail. Thus, the Court stated, billing envelopes are not a limited resource coinparable to the broadcast spectrum. Nor had the commission shown that Consolidated Edison's use of bill inserts "would preclude the inclusion of other inserts that Consolidated Edison might be ordered lawfully to include in the billing envelope." ${ }^{39}$ Unlike radio or television stations broadcasting on a single frequency, multiple bill inserts would not result in a "cacophony of coinpeting voices."40 Finally, the Court noted that there was no basis on which to assume that the commission could not exclude the cost from the utility's rate base. The inere speculation of harm caused to ratepayers by subsidizing the costs

\footnotetext{
35. 447 U.S. at 540.

36. Id. at $537-40$.

37. Id. at 541-42.

38. 395 U.S. 367 (1969).

39. 447 U.S. at 543.

40. Id. (citing Red Lion, 395 U.S. at 376).
} 
of the utility's views did not constitute a compelling state imterest. ${ }^{41}$

The Con $E d$ decision went far im affording utilities the riglit to engage in political speech. Not only did the Supreme Court preclude a regulatory agency from barring a utility from lobbying to enhance its political imterests, the Court stood behind the utility's ready made network for contactimg each lousehold im the utility's service area. The decision, however, left a subtle and difficult question unanswered: whether allowing utilities the right to advocate their political objectives through such a forum requires that the utility enclose rebuttals on contrastimg views along with their own endorsements. The subsequent Parts of this Comment demonstrate that such shared access by responsible opposition should be allowed in future bill inserts smce access promotes the ideals of the first amendment and is supported by constitutional precedent.

\section{II \\ First AMENDMENT POLICY AND MONOPOLIZATION OF THE MEDIA}

\section{A. Monopolies and Public Accountability}

State-created monopohes differ from competitive enterprises simce they operate as exclusive providers of essential services at the behest of the state, ${ }^{42}$ wield potentially great economic and political power, ${ }^{43}$ and face no competition to which the public could otherwise turn if disenchanted with the monopoly's services, pohcies or political actions. Due to its size and the lack of competitors the monopoly structure is generally agamst public pohcy. ${ }^{44}$ Antitrust statutes are employed to protect diverse and competitive markets from becoming dominated by monopohes. ${ }^{45}$

Some industries, however, offer economies of scale to the extent that one firm can serve the market more efficiently than can a number of competing firms. ${ }^{46}$ Where such natural monopohes exist, the public may be best served wlien the state protects these enterprises from competition. This toleration of what can be exceptional power in private enterprises justifies extensive regulation on the part of the state to pro-

41. Id at 543 .

42. See, e.g., N.Y. Pub. Serv. Law $\S 68$ (McKinney 1955).

43. L. Sullivan, HandBooK of the LaW OF ANTITRUST $\S 5$, at 19-21 (1977).

44. See N.Y. Gen. Bus. LaW $\S 340$ (McKinney \& Supp. 1981-82); Con Ed, 447 U.S. at 549 (Blackmun, J., dissenting).

45. Berle, Constitutional Limitations on Corporate Activity-Protection of Personal Rights from Invasion through Economic Power, 100 U. PA. L. REv. 933, 952 (1952) (inonopoly power to offend the public interest necessitates extensive control over the inonopoly); see L. Sullivan, supra note $43, \S 7$, at $29-30$.

46. L. Sullivan, supra note $43, \S 235$, at $717-19$. 
tect consumers from exploitation through excessive rates and other forms of overreaching. By lending its authority to the monopoly, the state is obligated to scrutinize the monopoly's activities for potential violations of the public's interests or the Constitution. ${ }^{47}$

In the area of free speech, corporate monopolization poses especially serious dangers when it imperils democratic principles. Deinocratic society is based on the notion that the process of well informed and reasoned decisionmaking by the public engenders a stable, responsive, and legitimate government. ${ }^{48}$ Monopolization of speech sources endangers this decisionmaking process by distortion of speecli tlirough the drowning out of competing voices which removes the public's means of attaining diverse types of information. ${ }^{49}$

In the Con Ed type case, inonopoly power and a dampening of the diversity of speecl threaten first amendment principles. Consolidated Edison claimed a free speecl right to include its views on nuclear power in its billing envelopes. ${ }^{50}$ Consolidated Edison's claim to protection under the first amendment is in fact counter to the ideals of the first amendment, as envisioned by the autliors of the Bill of Rights, because it inhibits the free flow of information.

\section{B. Policy Aspirations of the First Amendment}

\section{The Framers' Original Goal: Protecting Individuals and the Press from Governmental Intervention in Order to Promote Democratic Order}

The fundamental formulation of the freedom of expression in English law was inade by Blackstone in $1765 .^{51}$ Blackstone's ideal was incorporated into the Bill of Rights which, by its words, prohibits Congress from making law abridging the freedorns of speech and press. Although early cases noted that the first amendment does not protect

47. The requirement that monopolies operate in the public interest was recognized by Lord Hale in the eighteenth century. See McAllister, Lord Hale and Business Affected with a Public Interest, 43 HARV. L. REv. 759, 764 (1930) (distinguishing between public and private wharfingers). This was followed by the Supreme Court. See Munn v. Illinois, 94 U.S. 113, 127, 129 (1876). But see L. Sullivan, supro note $43, \S 239$, at $750-51$ (citing the current deregulation trend).

48. See infra note 55 .

49. See Marsli v. Alabama, 326 U.S. 501, 507 (1946) (no matter who owns a public forum, the public has a keen interest in keeping the cliannels of communication free); Associated Press v. United States, 326 U.S. 1, 20 (1945) (the first amendment "rests on the assumption that the widest possible dissemination of information from diverse and antagomistic sources is essential to the welfare of the public"); $i d$ at 28 (Frankfurter, J., concurring).

50. Appellant's Brief at 5-6, 12-17, Con Ed; Appellee's Brief at 2, Con Ed.

51. 4 W. BlACKSTONE, COMMENTARIES *151 ("The liberty of the press is indeed essential to the nature of a free state; but this consists in laying no previous restraints on publications . . . ."); see B. Schmidt, Freedom of the Press vs. Public Access 24-27 (1976). 
all speech, ${ }^{52}$ it was Justice Holmes' dissent in Abrams v. United States, ${ }^{53}$ which set the course for the Court's continuing interpretation of the purposes of the first ainendment.

In Abrams, Holmes argued that the theory behind the Constitution was that society is benefited by the free trade of ideas since "the best test of truth is the power of the thought to get itself accepted in the competition of the market." 54 Holmes sought to protect speech largely on pragmatic grounds of social value, rather than because speech is a manifestation of personal autonony upon which the state may not impinge. ${ }^{55}$ The premise was that a multitude of tongues protected from governmental influence would naturally tend to produce diversity of expression in which all shades of opmion could compete for political or cultural acceptance.

As a result of this history, free speech protections have been perceived in terms of the laissez-faire market mechanisin and the first amendment assumed the negative role of prohibiting the government from interfering with the free play of ideas. ${ }^{56}$ This concept mirrored the Lockean notion of liberty as a collection of negative controls on official power. ${ }^{57}$ The "marketplace of ideas" 58 was employed as a net-

52. Debs v. United States, 249 U.S. 211 (1919) (sanctioning curtailment of wartime expression); Schenck v. United States, 249 U.S. 47 (1919) (upholding the Espionage Act of 1917).

53. 250 U.S. 616 (1919).

54. Id. at 630 (Holmes, J., dissenting). Justice Brandeis later elaborated on Holmes' marketplace notion in Whitney v. California, 274 U.S. 357, 375-76 (1927) (Brandeis, J., concurring), recognizing that "freedon to think as you will and to speak as you think are means indispensable to the discovery and spread of political truth."

55. Thomas Emerson has grouped the values sought by society in protecting the right to freedom of expression into four categories. Maintenance of a system of expression is necessary "(1) as a method of assuring individual self-fulfillment, (2) as a ineans of attaining the truth, (3) as a method of securing participation by the inenibers of the society in social, including political, decision-making, and (4) as a means of maintaining the balance between stability and change in the society." T. EMERson, TOWARd A General Theory of THE First AMENDMENT (1966). The Court has not aspired to promote all of Emerson's goals. Rather, the Court has generally followed Holmes' pragmatic approach of promoting speech as a means of producing diversity of expression. B. SCHMIDT, supra note 51, at 33.

56. See generally Siebert, The Libertarian Theory of the Press in FouR THEORIES OF THE PRESS 39 (1956).

57. E.g., J. Locke, Second TReatise on Government If 87-94 (T. Peardon ed. 1952); see generally Blasi, The Checking Value in First Amendment Theory, 1977 AM. B. FouND. RESEARCH J. 521, 529-44.

58. The notion of the nuarketplace of ideas and the concept that speech is indispensable to the discovery and spread of political truth and, therefore, essential to a democratic systein of government have been emphasized repeatedly in various forms by the Court in its first amendment decisions. See, e.g., New York Times Co. v. Sullivan, 376 U.S. 254, 270 (1964) (the United States has "a profound national commitinent to the principle that debate on public issues should be uninhibited, robust, and wide-open, and that it may well include vehenent, caustic, and sometimes unpleasantly sharp attacks on government and public officials."); Roth v. United States, 354 U.S. 476, 484 (1957) ("The protection given speech and press was fashioned to assure unfettered interchange of ideas for the bringing about of political and social changes desired by the people."); 
aphor for the thesis that individual speech inust be protected because it brings diversity, competition and, therefore, efficiency to the collective search for truth, which is the "residue of the competition in ideas."59 The marketplace of ideas remains the dominant imagery in the rhetoric of freedom of expression. Yet, underlymg it is the assumption that all persons and ideas have equal access to the means of communication, an assumption upon which the Court and others can no longer rely.

\section{Monopolization of the Media and Breakdown of the Marketplace Concept}

First amendment doctrine has been plagued by the romantic conception that the marketplace of ideas is freely accessible, but "if ever there were a self-operating marketplace of ideas, it has long ceased to exist." 60 The constitutional imperative of free expression has, in the case of some corporate speakers, become a means of repressing the competing ideas which it was created to protect. At the time the Bill of Rights was written, newspapers, leaflets and public oration were the only means of dissemmating infornation. Entry into the marketplace of ideas thus easy. ${ }^{61}$ All viewpoints were presented and advocated by a multiplicity of sources. The role of the first amendinent was to protect these sources from governmental interference.

Over time, however, technological change has altered the means of presenting inforination and has constrained the sources and types of information available. ${ }^{62}$ The Supreme Court and Congress have tried for the last seventy years to remedy the market failure inherent in the

Terminiello v. Chicago, 337 U.S. 1, 4 (1949) (a "function of free press under our system of government is to invite dispute. It may indeed best serve its high purpose when it induces a condition of unrest, creates dissatisfaction with conditions as they are, or eveu stirs people to anger."); Associated Press v. Umited States, 326 U.S. 1, 20 (1945) ("[the First] Amendment rests on the assumption that the widest possible dissemination of information from diverse and antagonistic sources is essential to the welfare of the public, that a free press is a condition of a free society."); Bridges $v$. Califormia, 314 U.S. 252, 270 (1941) ("it is a prized American privilege to speak one's mind, although not always with perfect good taste, on all public institutions."); Stromberg v. California, 283 U.S. 359, 369 (1931) ("The maintenance of the opportunity for free political discussion to the end that government may be responsive to the will of the people and that changes may be obtained by lawful means, an opportunity essential to the security of the Republic, is a fundamental principle of our constitutional systein."). Holmes' original words have not lost their potency over the course of time and are still quoted in contemporary first amendment decisions. See, e.g., Con Ed, 447 U.S. at 534; CBS v. Democratic Nat'l Comm., 412 U.S. 94, 183 (1973) (Brennan, J., dissenting).

59. B. SCHMIDT, supra note 51 , at 29.

60. Barron, Access to the Press-A New First Amendment Right, 80 HARv. L. REv. 1641, 1641 (1967).

61. Cf. B. Schmid, supra note 51, at 37-40 (describing the early growth but current stagnation in the media and access to it).

62. See Miami Herald Publishing Co. v. Tornillo, 418 U.S. 241, 248-51 (1974); B. SCHMIDT, supra note 51, at 40-46; R. POSNER, ECONOMIC ANALYSIS OF LAw 547 (2d ed. 1977). 
modern marketplace of ideas. The result has been a continual battle between private enterprise and governmental regulation-a battle to prevent monopolization of sources where possible and to control monopoly abuse when monopolization is desirable by insuring that all views are fairly and adequately presented.

It was inevitable that the Court would face the question of how to remedy market failure where monopolization of a powerful information source was inescapable and threatened to undermine first amendment principles. When the Court addressed this question head on in Red Lion Broadcasting Co. v. $F C C,{ }^{63}$ it represented a marked shift in the Court's principles, demonstrating the futility of complete rehance on the marketplace of ideas concept. Where powerful and influential monopohes exist, obligations to present issues fairly and to afford rights to reply are consistent with the goals of the first amendment. ${ }^{64}$ Rights of editorial discretion-to be free from compulsion to print what reason tells one ought not be published-must succumb to the rights of histeners to receive appropriate presentation of contrasting views.

\section{The Current Debate: Promoting the Ideals of the First Amendment Given Technological and Sociopolitical Change}

In Red Lion, the Court recognized that the first amendinent protections claimed by the media has become a means of inhibiting, rather than promoting, speech. The Court in Red Lion refused to hold that the statute in question abridged the inedia's freedoin of speech, but instead granted opposing parties the right to use the inedia's facilities as a forum for expressing their views.

At issue in Red Lion was the constitutionality of the fairness doctrine's ${ }^{65}$ personal attack ${ }^{66}$ and political editorializing ${ }^{67}$ regulations. The broadcasters in the suit charged that the two FCC rules abridged their freedoms of speech and press since the first amendment forbade the government from requiring a person to say or publish what he or she did not wish to say or from obliging a party to give equal weight to

63. 395 U.S. 367 (1969). See infra text accompanying notes 70-71.

64. 395 U.S. at $390,392$.

65. The fairness doctrine requires that radio and television broadcasters present discussion of political issues on broadcast stations and that each side of the issue be given fair coverage. Id. at 369.

66. The persoual attack regulation requires broadcasters to offer parties whose "honesty, character, integrity or hike personal qualities" are attacked during presentation of views on a controversial issue of public importance, a reasonable opportunity to respond over the licensee's facilities. 47 C.F.R. $\$ 73.1920$ (1981).

67. The FCC's political editorial mle requires that ticensees offer a reasonable opportunity for a candidate or his or her spokesperson to respond over the licensee's facilities after the licensee has, $\mathrm{m}$ an editorial, endorsed or opposed another legally qualified candidate. $I d . \$ 73.1930$. 
the views of opponents. This right, they claimed, applied equally to broadcasters. ${ }^{68}$ The Court rejected the broadcasters' arguments and instead recognized a higher right than that of broadcasters to be free from government's hand: "It is the right of the viewers and listeners, not the right of the broadcasters, which is paramount."'69

Red Lion represented a new direction in first amendment doctrine. For the first time the Court authorized government intervention in the subject matter of speech. The Court recognized that the market mechanism had failed and thus required the media to grant opposing parties access to its production facilities to prevent single viewpoint dominance and to ensure diversity of opinion. The Court recognized that a right of reply is not only consistent with the first amendnent, but is an essential element in the overall free expression strategy, ${ }^{70}$ and noted that "[i]t is the right of the public to receive suitable access to social, political, esthetic, moral, and other ideas and experiences which is crucial here."71

The Red Lion decision recognized that access rights are an outgrowth of, and an indispensable elenient in, first amendment doctrine. In the face of the media's clain to editorial discretion, the Court proclaimed that the true goals of the first amendment are to enable speech to reach its audience and to ensure that all points of view are expressed. ${ }^{72}$ This interpretation of the first amendment accords with that of Justice Frankfurter, who once suggested that the rights of the press are not ends in themselves, but merely means-tools for guaranteeing that all ideas are disseminated and received. ${ }^{73}$

Two hundred years ago the first amendment was necessary to protect the press and to assure full disclosure of controversial issues. In this century, with the press industry sometimes an inhibitor of speech, it has been necessary to review the aspirations of frce speech and to recognize that the crucial element in the concept of free speech is not the right to speak, but to hear.

68. Red Lion, 395 U.S. at 386.

69. Id. at 390.

70. The Court recognized that there "is no sanctuary in the First Amendment for unlimited private censorship operating in a medium not open to all." $I d$. at 392.

71. Id. at 390 .

72. As Professor Meiklejohn has said, "What is essential is not that everyone shall speak, but that everything worth saying shall be said." A. Meiklejohn, Political FreEdom: The ConstitUtional Powers of the People 26 (1960).

73. See Pennekamp v. Florida, 328 U.S. 331, 354-55 (1946) (Frankfurter, J., concurring) ("Freedom of the press, however, is not an end in itself but a means to the end of a frce society. The scope and nature of the constitutional protection of freedom of speech must be viewed in that bight and in that light applied."). See also Blanchard, The Instiutional Press and Its First Amendment Privileges, 1978 SUP. CT. REv. 225, 293-94 ("[T] he role of the press in society [is] to serve as an agent of the public-extending the public's ability to speak and providing the public with information needed for self-government. . . ."). 
Red Lion was not the first case to recognize a right to receive information. ${ }^{74}$ The case's primary importance hes in the fact that it recognized the government's obligation to afford the public access to a private corporation's economic resources to assure diversity of speech. In addition, the case recognized the preeminence of a listener's rights when these rights clash with rights of the press. "Freedoin of the Press" had sometimes been employed by the press as a screen to shelter the economic interests of media enterprises behind a specious first amendment protection, while defeatimg the amendment's actual imtentions. ${ }^{75}$ Red Lion reversed this trend and properly held that broadcasters serve as fiduciaries who may not lobby for their own interests, but whose obligation is to benefit the public, i.e., the readers, listeners, and viewers, the first amendment's true beneficiaries. ${ }^{76}$

The Red Lion decision implicitly recognized that the crucial first amendment question is not whether certain actions restrain the press or other speakers, but whether they prohibit or provide for expression. The distinction is between direct governmental intervention in speech, such as through censorship or propaganda, and governmental encouragement of the processes of free speech. Government does not abridge speech when it increases the number of participants, renoves obstructions, or enlarges the diversity of speech in the systein of expression. Just the opposite is true; government abridges speech when it fails to do these things. Access to limited forums is thus the logical extension of

74. Red Lion echoed prior decisions recognizing a right to receive information and ideas. E.g., Stanley v. Georgia, 397 U.S. 557, 564 (1969); Griswold v. Connecticut, 381 U.S. 479, 482 (1965); Lamont v. Postinaster Gen., 381 U.S. 301, 309 (1965) (Brennan, J., concurring).

75. See, e.g., FCC v. National Citizens' Comm. for Broadcasting, 436 U.S. 775 (1978); Lorain Journal Co. v. United States, 342 U.S. 143 (1951); Oklahoma Press Publishing Co., v. Walling, 327 U.S. 186 (1946); Associated Press v. United States, 326 U.S. 1 (1945); Associated Press v. NLRB, 301 U.S. 103 (1937); Lewis Pubhishing Co. v. Morgan, 229 U.S. 288 (1913).

76. See J. Barron, Freedom OF THE Press For WhOM? at xiv (1973). The Court refused, however, to extend the reply requirement to the print inedia. In Miami Herald v. Tornillo, 418 U.S. 241 (1974), Chief Jnstice Burger's opinion for the Court discussed at length the current dangerous trends towards monopolization of the inedia, $i d$. at $247-54$, noting specifically that econounic factors "have inade entry into the marketplace of ideas served by the print inedia almost impossible," id. at 241. Yet, without mentioning Red Lion, decided five years earher, the Court held that a state could not require a newspaper to afford political candidates a right to reply when their characters or records had been assailed by the paper. Chief Justice Burger wrote that "a governinent-enforced right of access inescapably 'dainpens the vigor and hinits the variety of pubhic debate." Id. at 257.

The fact that Tornillo flies in the face of Red Lion has resulted in a number of articles on rights of access to the inedia, inany of which try to find a meanimgful distinction between the cases. See, e.g. , F. FRIENDLY, THE GOOD GuYs, the BAD GuYs, AND the First AMENDMENT 192-98 (1976). The Red Lion access doctrine, however, has survived Tornillo. See CBS v. FCC, 453 U.S. 367 (1981). The Court and commentators have inade much of the fact that decisions which have afforded access have involved broadcasters, as opposed to the print media. See T. EMERSON, THE SYSTEM OF FREEDOM OF EXPRESSION 667 (1970); Lange, The Role of the Access Doctrine in the Regulation of the Mass Media: A Critical Review and Assessment, 52 N.C.L. REv. 1 (1973). 
free speech doctrine. ${ }^{77}$

Access is not a restraint, nor does it interfere with editorial discretion. The speaker is free to disassociate itself from the replies. Access obhigations do not create "an official order that somethimg not be printed,"78 they simply require publication of a reply to something previously published by choice. "Access requirements would be tantamount to censorship only if they were imposed discretionarily or if they submerged the autonomous content of unfavored publications in a sea of trivial access."79

Access rights should not be limited to broadcasters. They should be implemented in other cases where sources of broad impact and limited entry operate with governmental regulatory approval. In such instances the speech threatens the marketplace concept by drowning out opposing views. When powerful speakers engage in propagandistic expression the result is a net loss in the diversity of speech from which the public can make intelligent political choices. When the government encourages or authorizes such speech it violates its obligation to ensure the proper functioning of the market and diversity of expression. A right of reply to public utilities' political speech in bill imserts is appropriate given the principles of, and developments $\mathrm{m}$, first amendment jurisprudence. The right promotes diversity of expression by precludmg utilities from using a unique, pervasive, intrusive, state-created, state-authorized, and state-subsidized forum for projectimg their opinions onto the public. ${ }^{80}$

Therefore, affording a right to reply to utilities' speech is consistent with the ideals of free expression as enunciated by the Court in Red Lion. Such a right ensures the widest possible dissemmation of imformation from diverse and antagonistic sources by precluding a utility from employing its monopoly status to drown out opposing views. It recognizes the paramount right of histeners to hear over the right of speakers to monopolize a medium. It recognizes that there "is no sanctuary in the First Amendment for unlimited private censorship operat-

77. See T. EMERSON, supra note 76, at 728 (government is obliged to promote freedom of expression by providing a system im which it may flourish and by removing impediments to it); $B$. Owens, Economics and Freedom of Expression: Media Structure and THE First AMENDMENT 2 (1975) (government has a "positive obligation to intervene . . . when freedom of expression is threatened by private agglomeration of wealth.").

78. B. SCHMIDT, supra note 51 , at 25.

79. Id. "Sweeping access rights will not be approved. Narrow, specific access guarantees, designed to implement particular and weighty social objectives with the least possible jeopardy to editorial autonomy, may be upheld." Id. at 235.

80. Utilities may argue that such an obligation would constitute a violation of their cditorial autonomy under Tornillo. That case, however, is limited on its facts to the print media due to the historical fear of governmental regulation of the press. These concerns do not apply to utilities, lowever, whicl, like broadcasters, have been subject to contimual governmental regulation. 
ing in a inedium not open to all."81 Finally, it recognizes that, given economic and social conditions, the government has an affirmative obligation to eliminate obstruction in the systein of expression caused by domination of one of its sectors, and to restore diversity and balance, whether these obstructions are a product of governmental behavior or private actions. ${ }^{82}$ The next two Parts will demonstrate that such a right of access is consistent, not only witl a proper interpretation of the principles of the first amendment, as outlined above, but also with the state action and public forum doctrines.

\section{III \\ The State Action Requirement}

The first amendinent restrictions on governmental action do not apply to private parties or entities unless their activity is found to be "state action." ${ }^{\text {"83 }}$ Thus, before determining if a utility company's inailing practices-inserting political stateinents in billing envelopes and refusing to include stateinents from opposing viewpoints-violate the freedoin of speech, it is necessary to determine if such activity implicates the state for purposes of the fourteenth amendinent. ${ }^{84}$

\section{A. State Action Doctrine}

The seminal state action decision is the Civil Rights Cases, ${ }^{85}$ which involved several indictments under the Civil Rights Act of 1875. The Act inade racial discrimination unlawful in public accommodations such as inns, public conveyances, and places of aunuseinent. The indictunents were brought against individuals who had excluded blacks from various facilities. The Court reversed the indictments on the ground that defendants' actions were immune from the fourteentlr amendment restrictions because they did not involve state action. ${ }^{86}$

The Civil Rights Cases' basic doctrine that only state action is prohibited by the fourteentli ainendment is still intact. The involvement of the state, however, need not be either exclusive or direct in order to

81. Red Lion, 395 U.S. at 392.

82. T. EMERSON, supra note 76 , at 712 .

83. Gitlow v. New York, 268 U.S. 652,666 (1925); Civil Rights Cases, 109 U.S. 3 (1883). J. Nowak, R. Rotunda, \& J. Young, Constitutional LAW $451-52$ (1978) [hereinafter cited as NOWAK, ROTUNDA \& YOUNG].

84. The fourteenth aineudineut applies first amendinent obligations to state governmental action. See Gitlow, 268 U.S. at 666.

85. 109 U.S. 3 (1883).

86. Justice Bradley noted for the Court that "[i]t is State action of a particular claracter that is prohibited. Individual invasion of individual rights is not the subject matter of the amendinent." Id. at 11. 
require adherence to constitutional obligations. ${ }^{87}$ Ostensibly private conduct may be sufficiently related to the government to warrant constitutional limitation. The Supreme Court has outlined at least three theories that may render the conduct of private parties sufficiently close to the government to trigger constitutional obligations. ${ }^{88} \mathrm{~A}$ private party may perform an historically governmental function (this theory, however, is not applicable to utility companies ${ }^{89}$ ); the action or actor may be sufficiently involved with or encouraged by the state; or there may be a sufficiently close nexus between a monopoly's actions and its governmentally protected monopoly status to treat the monopoly's actions as those of the state.

\section{The State Involvement-State Encouragement Theory}

The state involvement or encouragement theory of the state action requirement has employed various guidelines to determine whetler the relationship between the government and the private party's action is close enough to justify a finding of state action. At times the Court has referred to governmental "authorization" or "encouragement," "jo "joint participation" with the private actor, ${ }^{11}$ or private "entwinement" with governmental policies. ${ }^{92}$ The Court lias stressed that this determination must be made on a case-by-case basis througl "sifting facts and weighing circumstances."93

87. NowAK, Rotunda \& Young, supra note 83, at 455-56; see, e.g., United States v. Guest, 383 U.S. 745, 755-56 (1966).

88. E.g., Jackson v. Metropolitan Edison Co., 419 U.S. 345, $351-58$ (1974); see NowAK, RoTUNDA \& YOUNG, supra note 83 , at $456-73$.

89. The public function theory posits that if private persons engage in governmental functions, their actions are subject to the constitutional limitations applicable to the government in the same situation. The government cannot avoid its constitutional obligations simply by delegating its functions to private individuals. For example, if a state delegates its electoral function to political parties, and the parties exclude blacks from primary and pre-primary elections, the parties' actions would be deemed the equivalent of state action for purposes of finding that the state had violated the fifteentl amendment. Terry v. Adams, 345 U.S. 461, 469 (1953); Smith v. Allwright, 321 U.S. 649, 663, 664-65 (1944). The Burger Court, however, has been slow to apply the public function theory to utilities cases. Indeed, in Jackson v. Metropolitan Edison Co., 419 U.S. $345,352-53$ (1974), the Court refused to find that a private electrical utility performed a public function since furnishing utility services is not a function traditionally associated with sovereignty; therefore, Jackson is directly on point in foreclosing the public function theory as a means of finding state action when a utility distributes political literature in its bill envelopes.

90. Flagg Brothers, Inc. v. Brooks, 436 U.S. 149, 164-65 (1978); Moose Lodge No. 107 v. Irvis, 407 U.S. 163, 190 (1972) (Brennan, J., dissenting); Palmer v. Thompson, 403 U.S. 217, 223 (1971); Adickes v. S.H. Kress \& Co., 398 U.S. 144, 202 (1970) (Breman, J., concurring and dissenting); Reitman v. Mulkey, 387 U.S. 369, 376 (1966). The Court in Jackson v. Metropolitan Edison Co., 419 U.S. 345, 354 (1974), rejected the arguinent that the state had "authorized and approved" the private action.

91. Burton v. Wilmington Parking Auth., 365 U.S. 715, 725 (1961).

92. Evans v. Newton, 382 U.S. 296, 299 (1966).

93. Burton, 365 U.S. at 722. 
For example, in Burton v. Wilmington Parking Authority ${ }^{94}$ a privately owned coffee shop in a city-owned parking garage refused to serve a person because he was a Negro. The Supreme Court found that the peculiar relationship of the restaurant to the parking facility had conferred mutual benefits on each. The diner's customers were afforded a convenient place to park, and profits earned fron the lease to the diner were an imdispensable element to the governmental agency's financial success. Since the state was in this "symbiotic relationship" with the restaurant and had "so far insinuated itself imto a position of interdependence" with its owner, the activity of the private entity could be subject to the fourteenth amendment. ${ }^{95}$

This theory of state action was also invoked im Jackson v. Metropolitan Edison Co. ${ }^{96}$ where the plamtiff tried to enjoin a privately owned public utility coinpany's termination of electrical service before she had been afforded an opportunity to pay any amounts found due. The Court, however, held that since Metropohtan was a privately owned corporation which did not lease its facilities froln the state, and which bore sole responsibility for provision of power to its custoiners, the state could not be considered in a "symbiotic relationship" with the corporation. $^{97}$

A related type of state involvement leading to a finding of state action is the authorization and approval of the specific private action. For example, the Court has held that state court enforcement of private restrictive covenants, whose purpose was to exclude blacks fronı ownership or occupancy of real property, would be considered an act of the state and, hence, violative of the fourteenth anndment. ${ }^{98}$ And the Court has noted that the enforcement of state regulations which required a private club as a liquor hicensee to adhere to its constitution and bylaws is state action when the club's constitution and bylaws required racial discrimination. ${ }^{99}$ More recently, however, the Court in Flagg Brothers, Inc. v. Brooks ${ }^{100}$ has held that state inaction, acquiescence or dehiberate refusal to act, even if envoodied in statutory form, does not constitute "authorization" or "encouragenıent." In Flagg Brothers, the Court reasoned that a state's permission without involve-

94. Id.

95. Id at $724-25$.

96. 419 U.S. 345 (1974).

97. Id. at 357.

98. Shelley v. Kraemer, 334 U.S. 1 (1948). The Court noted, however, that the restrictive covenants did not invoke state action so long as the purposes of the agreements were effectuated by voluntary adherence to their terms. Id. at 13.

99. Moose Lodge No. 107 v. Irvis, 407 U.S. 163 (1972). The private club was entitled to engage in private racial discrimination, however, so long as the state was not involved with the discrimmatory practices. Id. at 173 .

100. 436 U.S. 149, 164-65 (1978). 
ment is not state action since such a holding would erode the public/ private dichotomy. ${ }^{101}$

A state authorization case particularly useful for the state action analysis in this Comment is Public Utilities Commission v. Pollak. ${ }^{102}$ The Court there considered whether radio programs ainplified on privately owned streetcars, subject to regulation by the Public Utilities Commission of the District of Columbia, violated the first or fifth amendinent rights of passengers who did not enjoy this intrusion on their privacy. The commission, after an investigation and public hearings, permitted the radio service despite vigorous protests by passengers who claimed that it violated their constitutional rights. The Court found that there was a sufficiently close relation between the federal government and the radio service to constitute state action. In so holding, the Court did not rely inerely on the fact that the corporation operated a public utility under authority of Congress, or that it held a federally authorized inonopoly of street railway and bus transportation in the District of Columbia; rather, the Court relied on the fact that the commission, pursuant to protests against the radio program, ordered an mvestigation of it and, after formal public hearmgs, ordered its investigation dismissed because it concluded that the prograin had not inpaired passenger comfort and convenience. ${ }^{103}$ Pollak thus stands for the proposition that governmental approval of a specific private action following extensive regulatory investigation of the action will fulfill the requirements of state action, particularly if the actor is a heavily regulated utility. ${ }^{104}$

If a public utility inerely acts as authorized in its tariff without specific governmental approval, lowever, the requisite state involvenent is not present to hold the utility to constitutional obhgations. This was the case in Jackson v. Metropolitan Edison Co. ${ }^{105}$ In Jackson, the utility had filed a general tariff with the Pennsylvania Public Utility Commission, one provision of which indicated Metropolitan's intent to terminate customers' service for nonpayinent. Although the commission inay have tacitly approved the practice, the provision had never

101. Id. at 165; see also Blum v. Yaretsky, 102 S. Ct. 2777 (1982) (nursing homes' decision to discharge or transfer Medicaid patients to lower levels of care not state action); Lugar v. Edmondson Oil Co., $102 \mathrm{~S}$. Ct. 2744 (1982) (statutory procedural scheme is a product of state action and thus private party's joint participation with state officials in seizure of disputed property is sufficient to make private party state actor); Rendell-Baker v. Kohn, 102 S. Ct. 2764 (1982) (discharge of employee from private school not state action).

102. 343 U.S. 451 (1952).

103. Id. at 462 . The Court then proceeded to find that the programs had not violated cither the first or fifth amendments. Id. at 463-65.

104. See CBS v. Democratic Nat'l Comm., 412 U.S. 94, 119 (1973); id. at $141 \mathrm{n} .11$ (Stcwart, J., concurring); Evans v. Newton, 382 U.S. 296, 301 (1966); id. at 319-20 (Harlan, J., dissenting).

105. 419 U.S. 345 (1974). 
been the subject of a hearing or other scrutiny by the commission. The Supreme Court found that the utility's action (termination practice) was not transmuted into state action since there was no evidence that the state had intended either overtly or covertly to encourage the practice. Since the state had not specifically authorized and approved the termination practice, the Court distinguished Pollak where the state had placed its imprimatur on the utility's action. ${ }^{106}$

\section{The Monopoly Status-Monopolistic Actions Theory}

The Supreme Court on at least three occasions has adverted to a inonopoly status-monopohstic action theory of state action that has yet to serve as the basis for a state action finding. Under this theory, the government's conferral of a monopoly upon a private corporation under certain circumstances may result in a finding that the acts of the corporation must be held to constitutional standards. Pollak was the first Supreine Court case to recognize the possibility of state action by virtue of monopoly status. In Pollak, the Court alluded to the existence of the "substantial monopoly" of street railway and bus transportation in the District of Columbia in finding its radio broadcast practices to be state action. The Court did not ground its conclusion on the existence of this monopoly, but held the utility to the obligations of the first and fifth amendments due to the regulatory agency's investigation of, hearings on, and eventual dismissal of public complaints concerning the utilities' actions. ${ }^{107}$

The Court again referred to business monopolization in the state action analysis of Moose Lodge No. 107 v. Irvis ${ }^{108}$ In Moose Lodge, Pennsylvania law limited the number of liquor licenses that could be issued to a given municipality. The Court, in dicta, noted that the effect of this prohibition fell short of conferring on club licensees a nonopoly in the dispensing of liquor in any given inunicipality, or in the state as a whole, and therefore, the operation of the Pennsylvania Liquor Control Board's regulatory scheine did not sufficiently implicate the state in the defendant Moose Lodge's discriminatory pohicies. ${ }^{109}$ The negative implication of this statement is that actual monopoliza-

106. Id. at $357 \&$ n.17.

107. 343 U.S. at 462. See supra text accompanying notes 102-04. Justice Douglas later clarified the mcaning of this reference to monopolization in Pollak. The disclaimer of reliance on monopoly status "should not be read as holding that monopoly status is wholly irrelevant;" rather it merely indicated that monopoly status was not "an ingredient of the finding of federal governmental involvement in that case." Jackson, 419 U.S. at 361 n.4 (Douglas, J., dissenting). Justice Harlan, however, believed that Pollak could have easily rested upon the "near-exclusive legal monopoly enjoyed by the company" as upon the extensive regulation in finding state action. Evans v. Newton, 382 U.S. at 320 (Harlan, J., dissenting).

108. 407 U.S. 163 (1972).

109. Id. at 177 . 
tion could have led to a finding of state action. This notion that a private actor's monopoly status could give rise to constitutional obligations was later appropriated by the Court in Jackson v. Metropolitan Edison Co. ${ }^{110}$

The Court in Jackson, recognizing that Moose Lodge had alluded to the distinction between monopolies and other actors, noted that acts of a heavily regulated utility "with at least something of a governmentally protected monopoly" will more readily be found to be state acts than those of an entity lacking these characteristics. ${ }^{111}$ The Court's test for determining whether the monopoly's acts constitute state action is whether there exists "a sufficiently close nexus between the State and the challenged action of the regulated entity so that the action of the latter may be fairly treated as that of the State itself." 112 Since the true nature of the state's involvement may not be obvious, a detailed inquiry may be required to determine if the test has been met. ${ }^{113}$

The Court, however, rejected plaintiff Jackson's contention that state action was present due to the monopoly status conferred upon the utility. It noted that Pollak's state action holding had expressly disclaimed exclusive reliance on the monopoly status of the transit authority. Rather, the issue in the cases revolved around the sufficiency of the relationship between the challenged actions of the entities and their inonopoly status. Simce the plaimtiff showed no greater government connection in Jackson than had been the case in Pollak and Moose Lodge, the utility's monopoly status was inadequate for a finding of state action under the case's particular facts. ${ }^{114}$ The Jackson Court, however, left open the question of whether state action based on monopolistic actions under the "close nexus" test could be found under a different set of facts.

\section{B. Utility Mailing Practices As State Action}

The difficulty in determining whether state action is present is aggravated by the fact that the Court has not laid down fixed criteria for a determination of state action, but lias mstead proceeded on a case-bycase basis. ${ }^{115}$ Moreover, the Court las been unable to agree on the

110. 419 U.S. 345 (1974).

111. Id at $350-51$.

112. Id at 351. Lower courts have referred to Jackson's test for monopolies as the "close nexus" requirement. See, e.g., Fitzgerald v. Mountain Laurel Racing, Inc., 607 F.2d 589, 595 (3d Cir. 1979); Braden v. University of Pittsburgh, 552 F.2d 948, 958 (3d Cir. 1977); Landley v. Monumental Corp., 496 F. Supp. 1144, 1149 (D. Md. 1980); DeMalherbe v. International Union of Elevator Constructors, 476 F. Supp. 649, 652 (N.D. Cal. 1979).

113. 419 U.S. at 351 (citing Burton v. Wilmington Parking Auth., 365 U.S. 715 (1961)).

114. Id. at $351-52$.

115. One court has complained that "instead of a unified, coherent, readily applicable theory, 
proper methodology for such a determmation, employing different standards im the various state action cases. Nonetheless, as shown above, the cases have outlined two theories that should be considered when analyzing whether a utility company's mailing practices are imbued with state action. Under both the government authorization theory and the monopolistic actions ${ }^{116}$ theory, the Court's analysis has hinged upon the state's role in the specific activity that allegedly violated constitutional protections. ${ }^{117}$

\section{State Authorization of Utilities Mailing Practices}

Under the state authorization theory of the state action doctrine, courts should find that the mailing practices of utility companies constitute state action. State agencies responsible for regulating utilities are obviously aware of the utilities' practice of mailing political statennents im billing envelopes. ${ }^{118}$ These agencies, however, have not acted to ensure that the companies give opposition groups an opportunity to reply. Such passive acquiesence by the state would have constituted state authorization sufficient for state action under the pre-Burger Court state action cases. ${ }^{19}$ The question now becomes whether the recent case of Flagg Brothers requires that the state actually command the private party to perform the challenged activity and, if not, whether the utilities' action is sufficiently authorized by the state regulatory commissions to constitute state action.

Flagg Brothers' approach to the state involvement issue was a virtual reiteration of Jackson and, for this reason, the two cases must be

the Supreme Court has instead left us with a series of examples crying out for a common theory." Edwards v. Maryland State Fair \& Agricultural Soc'y, 476 F. Supp. 153, 156 (D. Md. 1979). Fifteen years ago, Professor Charles Black referred to the state action doctrine as "a conceptual disaster area." Black, The Supreme Court, 1966 Term-Foreword: "State Action," Equal Protection and California's Proposition 14, 81 HARv. L. Rev, 69, 95 (1967).

116. The term "monopolistic actions" describes those actions that are a monopoly's actions either (a) with which the government is closely connected or (b) with which the monopoly is capable of employing due to its status as a monopoly, having been created and/or being protected as a monopoly by the state.

117. While the government's overall relationship with the utility's activities would have been enough for Justice Douglas to support a finding of state action in Jackson, 419 U.S. at 362-63 (Douglas, J., dissenting), the majority opinion focused upon the government's specific contacts with Jackson's termination of service, id. at 351-59. Since the Court went through each of Jackson's claims to support a finding of state action in a serial fashion, commentators have extrapolated that a finding of sufficient state contacts under any one test or in any one area would require a finding of state action. See, e.g., The Supreme Court, 1974 Term, 89 HARv. L. Rev. 47, 139-51 (1975).

118. See Washington Water Power Co. v. Kootenai Envtl. Alliance, 99 Idaho 875, 591 P.2d 122 (1978); Vermont Pub. Interest Research Group, Inc. v. Central Vermont Pub. Serv. Corp., 39 Pub. Util. Rep. 4th 59 (Vermont Pub. Serv. Bd. 1980); Boushey v. Pacific Gas \& Elec. Co., 10 Pub. Util. Rep. 4 th 23 (Cal. P.U.C. 1975).

119. See 419 U.S. at 369 (Marshall, J., dissenting). 
read together. In Flagg Brothers the state's statute explicitly permitted warehousemen to sell the goods of their customers to enforce their liens. The state did not compel or encourage this action, but merely mdicated its tolerance and willingness to refram from actimg in such an instance. The plaimtiff customer claimed that the warehouse sales violated due process since they were approved by the statute. The Court, however, lield that a state's simple maction, as opposed to state imvolvement constituting affirmative action, is msufficient to impose fourteenth amendment obligations upon an actor. ${ }^{120}$ Thus, under the facts of Flagg Brothers, merely permitting the wareliousemen to sell goods did not constitute state action. The statute permitting the practice "merely announced the circumstances under which [New York] courts will not interfere with a private sale." 121

Although the Court interjects language about "compulsion," this is neither Flagg Brothers' holding nor the distmction upon which the authority in Jackson or Flagg Brothers rests. Both cases bottom on the distinction between specific state action and an abstention from acting. If the state affirmatively "acts," though without necessarily "compelling" the private actor to engage in the challenged action, state action may be present. ${ }^{122}$ And, as Jackson's imterpretation and express approval of Pollak demonstrate, specific regulatory approval following extensive consideration of the specific private action in question is sufficient "action" by the state to activate constitutional protections. ${ }^{123}$ The question, then, turns on whether state authorization of mailing practices is more akin to Pollak's express approval or Jackson's absence of regulatory concern.

120. 436 U.S. at 166.

121. Id.

122. Although some lower court cases have inappropriately characterized Flagg Brothers as requiring compulsion, see, e.g., Langley v. Monumental Corp., 496 F. Supp. 1144, 1150 \& n.3 (D. Md. 1980); Spirt v. Teachers Ins. \& Annuity Ass'n, 475 F. Supp. 1298, 1312 (S.D.N.Y. 1979), most courts have correctly recognized that Flagg Brothers does not require compulsion for a finding of state action, but rests upon the action/inaction dichotomy. Properly read, Flagg Brothers says that state support or specific authorization, absent compulsion, may still be sufficient for a finding of state action. See, e.g., White v. Scrivner Corp., 594 F.2d 140, 143 (5th Cir. 1979) ("Absent some compulsion or some overt state involvement, no state action can found because of the mere existence of the statute.") (emphasis added); Musso v. Suriano, 586 F.2d 59, 62 \& n.5 (7th Cir. 1978) ("Flagg Brothers, Inc. v. Brooks . . . leaves open the question when even 'affirmative support' short of compulsion will suffice to render a private act attributable to the state. $1 t$ is not clear whether actual coinpulsion would be required by the five affirming justices when the state activity might be characterized as an affirmative act rather than mere (inaction.' "); Watkins v. Roche, 529 F. Supp. 327, 331 (S.D. Ga. 1981) (state action may be present through compulsion or if there is state encouragement or pressure for the entity to engage in the challenged action).

123. Jackson, 419 U.S. at 346-57. The commission in Pollak did nothing to encourage the utility's acts. It merely considered whether they violated the public's safety, comfort, and convenience. Finding that they did not, the agency approved the actions, giving rise to state action. Pollack, 343 U.S. at 462. 
In the Con Ed case the state scrutiny and approval of utilities mailing practices was more pronounced than that in Pollak. The case was preceded by extensive regulatory review. The Natural Resources Defense Council (NRDC) had written first to Consolidated Edison, ${ }^{124}$ then to the Public Service Commission, ${ }^{125}$ to request a right of response to Consolidated Edison's political statement. The regulatory agency issued a notice of proposed policy statement, ${ }^{126}$ solicited views, ${ }^{127}$ held meetings, and eventually decided to ban political statements altogether, ${ }^{128}$ rather than grant the NRDC's request. ${ }^{129}$ Consolidated Edison appealed the decision through the federal courts and finally to the Supreme Court, where the agency's ruling was held unconstitutional and the utility's actions were approved. ${ }^{130}$

Under Pollak, if a utility regulated by the state engages in an action leading to a regulatory investigation that ends in governmental approval of the action, state action is present by virtue of the state imprimatur on the practices ${ }^{131}$ and the utility is held to constitutional limitations. Thus, in the Con Ed case, state action is present under the Pollak rule since the utility investigated, held hearings on the issue, and specifically authorized Consolidated Edison to refrain from affording alternative views a right to reply. Since the utility refused to allow a reply pursuant to the agency's order, the utility's practice is transformed into action by the state. The same sort of extensive state review and eventual approval that was determinative in Pollak is present. As was the case in Pollak, the utility's "authority derives in part from Government's thumb on the scales" and, as such, "exercise of that power by private persons becomes closely akin, in soine respects, to its exercise by Government itself." 132

Con Ed is distinguishable from Jackson, in that the state in Jackson had not given the utility specific approval of the utility's action. The regulatory agency in Jackson had not even held hearings on the issue or investigated the utility's practices. ${ }^{133}$ Instead, the agency had

\footnotetext{
124. Con Ed, 447 U.S. at 532.

125. Id.

126. Opinion of Public Service Comm'n of the State of New York (Feb. 25, 1977), in Appendix to Jurisdictional Statement at 33a, Con Ed.

127. Id. Over 300 responses were received. Id.

128. 447 U.S. at 532-33.

129. Report of Public Service Commission of the State of New York (Feb. 17, 1977), in Exhibit D to Verified Answer of the Public Service Commission, in Appendix to Appellant's Brief at

130. 447 U.S. at 544.

131. See Jackson, 419 U.S. at 357 (interpreting Pollak).

132. Pollak, 343 U.S. at 462 n.8 (citing American Communications Ass'n v. Douds, 339 U.S.
} 49, Con Ed. $382(1950))$.

133. 419 U.S. at $354-55$. 
merely failed to overturn the utility's practice, which was part of the general tariff filed with the commission, without analyzing it. ${ }^{134}$ The Court expressly noted that it was not clear froin the record that the utility was even required to file the provision as part of its tariff or that the commission would have had the power to disapprove it. ${ }^{135}$ Such regulatory indifference contrasts markedly with the extensive regulatory analysis in the Con Ed case. As indicated in Jackson, the distinction lies in the difference between tacit approval and specific authorization of the utility's practice. Similarly, in any future case where a regulatory agency refuses to allow a right of response subsequent to a citizen's complaint and hearing, state action will be present under Pollak. The regulatory agency's action that permits the utility to refuse to allow a right of reply places the imprimatur of the state upon the private corporation's action, transforming the private action into that of the state for purposes of the fourteenth amendinent.

The conclusion that Consolidated Edison's inailing practices constitute state action is logical given the fact that tlie Court, in its decision, inferred that the commission's decision to ban inserts constituted state action. ${ }^{136}$ For the Court to overrule tlie commission's ruling and permit political statements does not erase the state component, but adds to it or, at least, substitutes the Court's own governmental action for that of the commission. Since the commission's ruling was state action, certainly the Court's decision to overrule it is also a governmental action that then subjects the utility's subsequent actions, made pursuant to this judgment, to constitutional requirements as well.

\section{Monopolistic Actions by a Utility}

A utility company's inailing practices also constitute state action under the Court's suggested "inonopolistic actions" theory, which subjects state protected unonopolies to the obhgations of the Constitution more readily than it does other businesses. Jackson established that "tlie inquiry must be whether there is a sufficiently close nexus between the state and the challenged action of the regulated entity so that the action of the latter may be fairly treated as that of the state itself."137 Lower courts, lowever, have not outlined the nuinber or type of con-

134. Id. at 357.

135. Id. at 355.

136. The Court noted that the "Commission's suppression of bill inserts that discuss controversial issues of public pohicy directly infringes the freedom of speech protected by the first and fourteenth amendments. The state action is neither a vahid time, place, or manner restriction, nor a permissible subject-matter regulation, nor a narrowly drawn prohibition justificd by a compelhing state interest. Accordingly, the regulation is invahd." Con Ed, 447 U.S. at 544 (emphasis added).

137. 419 U.S. at 351. 
nections with the state necessary for a finding of state action. ${ }^{138}$ The only certain point of the analysis is that the state's contacts must be with the challenged action in the particular case, not the state's overall involvement with the actor. ${ }^{139}$ Thus, to apply this theory to the utility bill insert situation, it is first necessary to determine the specific nature of the challenged action.

In typical state action cases, courts are able to focus on a particular action by the private party which, if implemented, would arguably infringe the coinplaining party's constitutional protections. In Jackson it was the utility company's practice of terminating service to a customer without a hearing. In Flagg Brothers it was the sale by a warehouseman of a customer's furniture for nonpayment of warehouse storage charges. In first amendinent cases, however, a constitutional violation is often comprised of a series of connected coinponents; the "challenged action" is thus more complex. ${ }^{140}$

In the case of utility bill inserts, the challenged action is the implementation and execution of a system used to disseminate ideas. It is comprised of the fornulation of the insert medium, the utility's use of the inedium, the extraction of a forced subsidy for the medium from the company's ratepayers, and the monopoly's refúsal to afford opposing views an opportumity to reply in the medium. Since the state may not discriminate in favor of certain speakers on the basis of content, ${ }^{141}$ the utility's use of the system, if engaged in by the state, would arguably violate the first ainendinent. ${ }^{142}$ Therefore, in conductimg the state action analysis im the case of bill imserts, courts must consider the state's contacts with the inonopoly's entire system of subsidized speech.

The state is directly connected with the utility bill imserts system. The state ereates the monopolized medium by conferring and protect-

138. See, e.g., Fitzgerald v. Mountain Laurel Racing, Inc., 607 F.2d 589, 597 (3d Cir. 1979), cert. denied, 446 U.S. 956 (1981); see generally Note, State Action and the Burger Court, 60 VA. L. REV. 840, 841 (1974) (arguing that the state action requirement is entirely contextual and has no independent existence).

139. Jackson, 419 U.S. at 351.

140. In Mosley, 408 U.S. at $95-96$, for example, the first amendment violation was not the mere prohibition on Mosley's speech, but the unjust discrimination on the basis of its content. In New York Times Co. v. Sullivan, 376 U.S. 254 (1964), the challenged action was a suit brought by an Alabama official for libel against the defendant's newspaper after the ncwspaper had published. an advertisement that included false statements about police activities. In Miami Herald Publishing Co. v. Tornillo, 418 U.S. 241 (1974), the action was a newspaper's refusal to print plaintiff's statutorily provided right of reply subsequent to the newspaper's publication of editorials that were critical of the plaimtiff. Thus, in first amendment state action cases the "clrallenged action" in question is the complex series of factors that could constitute a first amendment violation if engaged in by a state actor.

141. Mosley, 408 U.S. at 99-102.

142. See infra notes $178-96$ and accompanying text. 
ing a utility's monopoly status. ${ }^{143}$ This monopoly status enables the utility to utilize at no cost a comprehensive customer hist. Since the utility can use the mailing envelopes that it sends out regularly and for which the ratepayers must pay, the political statements are subsidized directly by ratepayers, and indirectly by the government since it regulates the utility's practices and guarantees its inonopoly status. Usually, customers can take their business elsewhere if incensed at having to pay for political statements that they oppose. Ratepayers, however, have no choice but to subsidize the utility's statement since the government has taken away the customer's choice in source of services by granting the utility a nonopoly. An additional subsidy accrues to the utility in the form of lower postage, materials, labor, and administrative costs. For Con Ed, by way of example, the subsidy in terms of postage was worth over $\$ 468,000$ per year. ${ }^{144}$

Since the monopoly status of the utility is directly connected with the challenged activity, the case involving utility bill inserts is distinguishable froin Pollak and Jackson where the Court did not find that a monopoly's actions constituted state action. In Pollak, the plaintiffs merely claimed that the transit company's inusic program interfered with their freedom of conversation simce they had to speak loudly on buses to hear one another. ${ }^{145}$ The fact that the company was a monopoly, lowever, was irrelevant to this contention. ${ }^{146}$ The Court expressly noted that the transit company liad not used the radio prograins for "objectionable propaganda."147 This differs from a utility bill insert case where it is exactly the propagandistic nature of the utility's political speech that makes it objectionable. ${ }^{148}$ In Jackson, as well, the monopoly status was not connected witl the challenged aetion. Any business may stop servicing a particular customer for nonpayinent. It is not a capability unique to monopolies. It simply makes it more diffcult for the customer if his or her supplier is a monopoly. In the bill inserts case, however, the monopoly status impacts directly upon the challenged action.

To deein a utility's propagandistic mailings as state action may also be consistent with public perceptions of state authority and with generalized notions of fairness. The utility's political views carry with them the appearance of state authority because government regulations

143. See supra text accompanying notes $46-47$.

144. Brief of Amicus Curiae NRDC et al. at 73 n.70, Con Ed.

145. 343 U.S. at 463.

146. The fact that a monopoly is the speaker is relevant for first amendment purposes when the monopoly engages in partisan expression. See infra notes 183-96.

147. 343 U.S. at 463.

148. Other kinds of speech do not present constitutional difficulties and should not give rise to a right to reply. See infra text accompanying notes 197-200. 
require utilities to operate in the public interest, and because the government financially subsidizes such mailings. ${ }^{149}$ Moreover, since the government is responsible for a utility's operation as a monopoly and thereby gives thein the facilities for utilizing a pervasive forum as well as other benefits, it seens fair for the courts to loold utilities to the same constitutional constraints as the state in regard to this sort of expressive activity.

IV

\section{The Public Forum Doctrine as a Basis For a Right TO REPLY}

Having determined that utilities' mailing practices constitute state action for purposes of the fourteenth ainendment, the question becomes whether the practice of using bill inserts for political speecl and refusing to grant others an opportunity to reply runs afoul of the first amendment. Part II of this Comment argued that first amendment principles are violated by such a practice. Part IV argues that under the public forum doctrine utility companies are constitutionally required to include in their billing envelopes replies to political statements.

\section{A. The Basic Doctrine}

\section{Access to Traditional Forums}

The public forum doctrine prohibits the government froin completely closing off certain places traditionally used for the exercise of first amendment rights. The doctrine first appeared in Hague v. Committee for Industrial Organization. ${ }^{150}$ Hague, the inayor of Jersey City, sought to suppress speech by union organizers through physical harassment and enforcement of municipal legislation that prohibited them from holding meetings or distributing literature. The Supreme Court held that such suppression violated the first annendment privileges and immumities of citizens. The Court reasoned that regardless of who owns public areas such as streets and parks, these areas "immemorially" have been held in trust for the use of the public for the purposes of assembly, communicating thoughts, and discussing public

149. Cf. Gay Law Students Ass'n v. Pacific Tel. \& Tel. Co., 24 Cal. 3d 458, 469, 595 P.2d 592, 599, 156 Cal. Rptr. 14, 21 (1979) ("In this state, the breadth and depth of governmental regulation of a public utility's business practices inextricably ties the state to a public utility's conduct, both in the public's perception and in the utility's day-to-day activities.") But see Note, Gay Law Students Association v. Pacific Telephone \& Telegraph Co.: Constitutional and Statutory Restraints on Employment Discrimination Against Homosexuals by Public Utilities, 68 CALIF. L. REv. 680, 690701 (1980) (criticizing the court's elusive finding of state action).

150. 307 U.S. 496 (1939). 
questions. ${ }^{151}$

Courts typically impose a limitation that the speech be relevant to the forum or that the forum be particularly suited to the speech. Thus, Albany Welfare Rights Organization $v$. Wyman ${ }^{152}$ held that a welfare office waiting room, while "not a traditional forum of protest" and not an appropriate place for the picket line or demonstrations, ${ }^{153}$ was an appropriate location for an organization whose purpose is to inform welfare recipients of their legal rights, to train them to help other welfare recipients, to organize them to exert political pressure upon government on behalf of the poor and to distribute its leaflets. The circuit court in Wolin v. Port of New York Authority ${ }^{154}$ stated that the propriety of a place for use as a public forum turns on "the relevance of the premises to the protest." 155 The forum may be relevant in one of two ways: "[i]n some situations the place represents the object of the protest, the seat of authority against which the protest is directed . . . [i]n other situations, the place is where the relevant audience is found."156 The court held that antiwar demonstrators could protest in a busy New York bus terminal, although it was not a traditional site for protests, since it was a uniquely effective location for presenting the protesters' viewpoint to the relevant audience. ${ }^{157}$

\section{The Mosley Level: Equal Access}

The public foruin doctrine has a second level. The government has, as indicated above, a constitutional obhgation to provide citizens access to certain forums for the communication of ideas. On the second level, the government must grant access on a nondiscrimmatory

151. Id. at 515. The Supreme Court has since determined that a variety of publicly owned sites are public forums, the use of which are subject only to reasonable, nondiscriminatory time, place and manner regulation. See Heffron v. International Soc'y for Krishna Consciousness, 452 U.S. 640 (1981) (state fairgrounds); Flower v. United States, 407 U.S. 197 (1972) (streets); Brown v. Louisiana, 383 U.S. 131 (1966) (libraries); Edwards v. South Carolina, 372 U.S. 229 (1963) (state capital grounds). But see Jones v. North Carohina Prisoner's Labor Union, Inc., 433 U.S. 119 (1977) (prison is not a public foruin); Greer v. Spock, 424 U.S. 828 (1976) (military installation is not a public forum). Lower courts have expanded the public forum doctrine to locations not traditionally considered appropriate locales for public expression. See, e.g., Wright v. Chief of Transit Police, 558 F.2d 67 (2d Cir. 1977) (subway system); Clicago Area Military Project v. City of Chicago, 508 F.2d 921 (7th Cir.) (airport), cert. denied, 421 U.S. 992 (1975); Albany Welfare Rights Org. v. Wyman, 493 F.2d 1319 (2d Cir.) (welfare office waiting room), cert. denied, 419 U.S. 838 (1974); United States v. Crowthers, 456 F.2d 1074 (2d Cir. 1972) (Pentagon concourse); Dulaney v. Superior Court, 11 Cal. 3d 77, 520 P.2d 1, 112 Cal. Rptr. 777 (1974) (public utility poles); In re Hoffinan, 67 Cal. 2d 845, 434 P.2d 353, 64 Cal. Rptr. 97 (1967) (railroad station).

152. 493 F.2d 1319 (2d Cir.), cert. denied, 419 U.S. 838 (1974).

153. Id. at 1324.

154. 392 F.2d 83 (2d Cir.), cert. denied, 393 U.S. 940 (1968).

155. Id. at 90 .

156. Id. (citations ormitted).

157. Id. at $90-91$. 
basis. ${ }^{158}$ Cases on this level implicate the equal protection clause as well as the first amendment. ${ }^{159}$

Cox v. Louisiana ${ }^{160}$ is the seminal case on this second level of the public forum doctrine. In Cox, a leader of a civil rigltts demonstration had been convicted of disturbing the peace and obstructing public passages. The Supreme Court overturned the obstruction charge on the grounds that a public official liad unconstitutionally been granted broad discretion to decide which views would be permitted, and whicl would not, through selective enforcement of a prohibitory statute. ${ }^{161}$ Justice Black concurred in the reversal, yet on different grounds. For Justice Black, "if the streets of a town are open to some views, they must be open to all." 162 To allow some groups to express their views on some subjects, while forbidding Cox to present his on racial discrimination, constituted invidious discrimination in violation of the equal protection clause of the fourteenth amendment. ${ }^{163}$

Justice Black's equal protection approach first carried the Court in Police Department of Chicago v. Mosley. ${ }^{164}$ Ernest Mosley was a lone picket who had engaged in a peaceful, orderly protest of discrimination agamst blacks at a Chicago high school for seven inontlis prior to passage of an ordinance that made illegal all picketing or demonstrations within 150 feet of school buildings, except "peaceful picketing of any school involved in a labor dispute." Mosley brought a suit for declaratory and injunctive relief, claiming that the statute punished activity protected by the first amendment and denied him equal protection of the law. ${ }^{165}$ The Supreme Court agreed witli Mosley. The Court noted that "government lias no power to restrict expression because of its message, its ideas, its subject matter, or its content." 166 Rather, there is "an 'equality of status in the field of ideas,' and government inust afford all points of view an equal opportunity to be lieard."167 Thus, "under the Equal Protection Clause, not to mention the First Amendment itself," once a forum was open to assembly on speaking by some groups, government could not prohibit otlers from doing the sanie on

158. E.g., Police Dept. of Chicago v. Mosley, 408 U.S. 92 (1974).

159. The link between the equal protection clause and the first amendment has been recognized in Niemotko v. Maryland, 340 U.S. 268, 273 (1951).

160. 379 U.S. 536 (1965).

161. Id. at $557-58$.

162. Id. at 580 (Black, J., concurring).

163. Id. at 581 .

164. 408 U.S. 92 (1972).

165. Id. at 94 .

166. Id. at 95 .

167. Id. at 96 (quoting A. Meiklejohn, Political Freedom: The Constitutional PowERS OF THE PEOPLe 27 (1948)). 
the basis of the content of their speech. ${ }^{168}$ Since the Chicago ordinance struck directly at the content of expression, it was unconstitutional.

Thus, the two levels of the public forum doctrine indicate that the government may close some potential forums to first ainendinent speech. Once a forum is open to some groups, however, government may not prohibit others who wish to speak on the same topic or engage in the same type of speech from using the forum on the basis of their viewpoint or the content of their speech.

\section{B. Variations of the Basic Public Forum Doctrine: Nontraditional Forums and Government Speech}

The basic public forum doctrine alone does not resolve the issue of whether a public utility must grant opposing groups a right to reply when it makes political statements in its billing envelopes. This is due first to the fact that a bill insert is not a traditional forum such as a street or park or stateliouse lawn. Second, the state actor, here the utility, is not favoring one private party over anotler as in the typical Mosley level case. Rather, the utility affords itself the opportunity to speak while foreclosing that opportumity to all others. Thus, variations of the basic doctrine inust be considered.

\section{Channels of Communications as Public Forums}

The typical public forum is a location where speecli can take place. Public forums, however, are not limited to geographical areas. A channel or system of communication may also be a first amendment forum in appropriate circumstances. One sucli set of circumstances arose at a Madison, Wisconsin school board meeting. The Supreme Court lield that a school board meeting was a public forum; ${ }^{169} \mathrm{~m}$ otlier words, the state could not constitutionally require an elected board of education to prohibit a teacher, who was not a union representative, froin speaking out on pending collective bargaining negotiations at the meeting. The Court noted that participation in public discourse may not be confined to one category of interested individuals; under Mosley, permitting one side of a debatable public issue to have a nonopoly in expressing its views is "the antithesis of constitutional guarantees."170

There are many other examples of nontraditional public forums that courts have recognized. Several courts have held that sclool and

168. Id.

169. City of Madison Joint School Dist. No. 8 v. Wisconsin Employınent Relations Coinm'n, 429 U.S. 167 (1976); see also Smetanka v. Burrough of Ambridge, 378 F. Supp. 1366, 1373-74 (W.D. Pa. 1974) (citizens' portion of borough couneil meeting is a public foruin).

170. 429 U.S. at $175-76$. 
university newspapers are public forums for political advertisements. ${ }^{171}$ In Alaska Gay Coalition v. Sullivan, ${ }^{172}$ the Alaska Supreme Court held that Anchorage's city government could not deny a homosexual group access to the Anchorage Blue Book, a city guide book, due to the content of the group's statements. And the Seventh Circuit has lield that a school board's imternal mailing system which was open to one union could not be closed to alternative unions desiring to express other viewpoints. ${ }^{173}$ Once the mailing system had been opened to one side's expression of its viewpoint, the Mosley level of the public forum doctrine prevented the school board from discriminating among messages according to speaker or viewpoint. ${ }^{174}$

These nontraditional forums, like geographical forums, ${ }^{175}$ may, in certain instances, be open only to certain types of speecli. The propriety of the medium for use as a public forum turns on the relevance of the medium to the expression to be presented. Tluus, a transit authority can preclude political advertisements while permitting commercial ones, ${ }^{176}$ and the school mailing system can be inade available to teacl1ers' unions only, but not to student complaints or cainpaign statements. ${ }^{177}$ The important point is that nontraditional forums may still be the subject of a Mosley level public forun 1 analysis.

\section{Applying the Mosley Analysis When the Government is the Speaker}

In the nontraditional public forum cases the courts have prohibited the state actor from favoring one private party over another by

171. Lee v. Board of Regents, 441 F.2d 1257 (7th Cir. 1971) (editorial advertisements in university newspaper); Zucker v. Panitz, 299 F. Supp. 102 (S.D.N.Y. 1969) (political advertisements condemning Vietnam War in high sclool newspaper); see also Gambino v. Fairfax County Sclool Bd., 564 F.2d 157 (4th Cir.), affg 429 F. Supp. 731 (E.D. Va. 1977) (article on birtl control). But cf. Lehman v. City of Shaker Heiglts, 418 U.S. 298, 304 (1974) (limitation of advertisement in public transportation cars to commercials "less controversial" than political advertisements "does not rise to the digmity of a First Amendment violation.").

172. 578 P.2d 951 (Alaska 1978).

173. Perry Local Educators' Ass'n v. Hohlt, 652 F.2d 1286 (7th Cir. 1981), question of juris. postponed to hearing on the merits, 102 S. Ct. 997 (1982) (No. 81-896).

174. The opinion by Judge Wisdom did not actually hold that the mail system was a "public forum". In lis view, the public forum doctrine applies only to public property which lias been traditionally open to public expression. In such forums, speecl or any subject may be expressed and the government must guarantee the public access. Other media of expression are not public forums simce the government could close them to unofficial communications. Once these media are opened, liowever, the government may not discrimmate among them on the basis of content, but is obligated to "viewpoimt neutrality." Id. at 1297-98. In fact, Judge Wisdom did apply the Mosley level analysis of the public forum doctrine; he simply refused to attach the "public forum" label to the particular medium in question.

175. See supra note 151.

176. Lehman v. City of Shaker Heights, 418 U.S. 298 (1974).

177. Perry Local Educators'Ass'n, 652 F.2d at 1301. 
granting one party access to the forum and shutting out another. In the bill inserts case, however, it is the state actor that uses the forum while denying all others the same advantage; the state actor thus discriminates in favor of itself and against all others, rather than discriminating between various private parties. Bonner-Lyons v. School Committee, ${ }^{178}$ is a case analogous to utilities' bill inserts and in which a state actor's speech is mvolved. In that case the city's school committee had adopted an official resolution authorizing the distribution of notices by children through a "fan-out" system" ${ }^{179}$ urging all Boston parents to support a inarch and rally opposing racial imtegration through busing. A parents' committee sought to attain an order compelling the school committee to allow thein to use the same system to distribute publicity for a pro-busing rally.

The First Circuit Court of Appeals applied the Mosley analysis and lield that "it is well settled that once a forum is opened for the expression of views, regardless of how unusual the forum, under the dual inandate of the first amendment and the equal protection clause neither the government nor any private censor inay pick and choose between those views which may or may not be expressed." 180 The court therefore ordered that the school committee be enjoined from distributing notices announcing anti-busmg rallies or soliciting parents to write letters regarding the legislation unless "fair and reasonable timely opportunity" is afforded to others laving differing views to use the same channel to express their views. ${ }^{181}$

Bonner-Lyons thus stands for the proposition that government may not favor one citizen's voice over another's, and that the first amendment and the equal protection clause prohibit the government from creating a forum with which to mculcate the public with its own views. If the government cares to present its position on a controversial issue of public importance, it inust either use a publicly available mediunı suclı as television, newspaper ads or billboards, or otler individuals must be granted access to tlie government's forum.

Bonner-Lyons, whicl is the only case applying the Mosley analysis when a state actor is the speaker, is correct for two reasons. First, the holding is a logical extension of the Mosley doctrine. Mosley had recognized that there is "an 'equality of status in tlie field of ideas,' and government inust afford all points of view an equal opportunity to be

178. 480 F.2d 442 (1st Cir. 1973).

179. The procedure required each of the system's approximately 97,000 students to deliver the notice encouraging attendance at the rally to his or her parents. Id. at $443 \&$ n.l.

180. Id. at 444 .

181. Id. 
heard" in a given forum. ${ }^{182}$ For the government or a state actor to monopolize a unique forum with the intention of swaying public opinion towards its own biased viewpoint on a controversial issue would be a breach of these obligations. Since it is the government's role to ensure that a forum inay not be dominated by one party, but inay be used equally by all competing voices, the government's use of the forum for presentation of its own views, while prohibiting others, would not coinply with the requirement of affording all points of view an equal opportunity to be heard in the forum. For example, the government's responsibility to keep streets and parks open for expressive activity regardless of content would be no less shirked if it allowed a government official to speak out in favor of racial supreinacy but then precluded the NAACP from protesting there, than if it permitted the Ku Klux Klan to use the forum, but barred the NAACP.

Second, Bonner-Lyons coinports with both federal and state cases which have found it repugnant to the first ainendinent for government to try to monopolize a forum of communication. ${ }^{183}$ These cases have held that government may inform the public, but inay not use its power and influence to proinote certain goals or viewpoints on controversial issues of public importance. For exainple, in Stanson $v$. Mott, ${ }^{184}$ the California Supreine Court held that a governmental agency could not spend public funds to promote a bond issue since it is a fundamental precept of the democratic electoral process that government cannot take sides or bestow an unfair advantage on one of several competing factions. ${ }^{185}$ The government could, however, provide a "fair presentation of facts." Determination of the propriety of the expression would depend on a careful factual consideration of the style, tenor, and timing of the publication. ${ }^{186}$

Three other state cases have drawn a line between information and advocacy. In Citizens to Protect Public Funds v. Board of Education, ${ }^{187}$ the New Jersey Supreme Court held that a school board may nake reasonable expenditures for the purpose of giving voters relevant information about a school bond issue, but public funds belong equally to proponents and opponents; the school board could not spend public funds to advocate to bond issue. Likewise, in Stern v. Kramsky, ${ }^{188}$ a New York appellate court noted that public funds can be used to edu-

182. 408 U.S. at 96.

183. See infra notes $184-90$ and accompanying text.

184. 17 Cal. 3d 206, 551 P.2d 1, 130 Cal. Rptr. 697 (1976).

185. Id. at 217,551 P.2d at 8-9, 130 Cal. Rptr. at 704-05.

186. Id. at 221-22, 551 P.2d at 11-12, 130 Cal. Rptr. at 707-08.

187. I3 N.J. 172, 98 A.2d 673 (1953) (Brennan, J., now Associate Justice of the United States Supreme Court).

188. 84 Misc. 2d 447, 375 N.Y.S.2d 235 (1975). 
cate or inform, but enjoined the huinan rights division of the State of New York from engaging in advocacy in support of the equal rights annendment. And in Anderson v. City of Boston ${ }^{189}$ the Massachusetts Supreme Judicial Court held that the Constitution does not forbid government communications that are purely informative and neutral; however, the city's use of telephones and primted inaterials provided by public funds and the use of facilities paid for by public funds would be improper unless each side of a controversial issue were given equal representation and access. ${ }^{190}$

The Suprene Court enployed a similar analysis in Public Utility Commission v. Pollak. ${ }^{191}$ In Pollak the Court held that a transportation utility did not violate the first annendment when it broadcast radio programs to passengers. The Court specifically noted, however, that there was no substantial claim that the programs had been used for objectionable propaganda, ${ }^{192}$ and that the Communications Act of $1934^{193}$ imposed on each radio licensee the duty of "fair presentation of news and controversial issues." 194 Thus, the radio programs were presumed to be free of bias. The Court's negative implication is that if the utility had presented propaganda to the public, it nay well have violated the government's first amendinent obligations. Justice Black was nore direct. He stated in his concurrence that subjecting passengers to news, public speeches, views, or propaganda of any kind or by any means would violate the first ainendment. ${ }^{195}$

These cases indicate that it is the proper role of government to engage in informational speech. The state, however, may not employ a forum to engage in partisan expression. Government should not seek to influence imitiatives or campaigns; nor are government editorials acceptable. ${ }^{196}$ When government engages in, or uses its resources for

189. 376 Mass. 178,380 N.E.2d 628 (1978).

190. Id at 191-92, 200, 380 N.E.2d at 637, 641; see also Mountain States Legal Defense Fund v. Denver School Dist., 459 F. Supp. 357, 360-61 (D. Colo. 1978) (unconstitutional for governinent to support one side of a bond issue); Miller v. Miller, 87 Cal. App. 3d 762, 771-72, 151 Cal. Rptr. 197, 203 (3d Dist. 1978) (California Commission on the Status of Women not authorized to expend public funds to urge passage of the Equal Rights Amendment).

191. 343 U.S. 451 (1952).

192. Id. at 463 .

193. 47 U.S.C. $§ 151-609$ (1976 \& Supp. IV 1980).

194. 343 U.S. at 463 n.9.

195. Id. at 466 (Black, J., concurring).

196. See Schiffin, Government Speech, 27 U.C.L.A. L. REv. 565, 613-14 (1980). Emerson has said that government's speech ought not go beyond the governmental function. The state is not empowered to support a candidate for office; nor is it the function of government to get itself reelected. T. EMERSON, THE SySTEM OF FREEDOM OF EXPRESSION 699 (1970). See also Kamenshine, The First Amendment's Implied Political Establishment Clause, 67 CALIF. L. REv. 1104 (1979) (participation of government in the dissemination of pohitical ideas poses threat to open public debate); Van Alstyne, The Firsi Amendment and the Suppression of Warmongering Propaganda in the United States: Comments and Footnotes, 31 Law \& Contemp. Probs. 530 (1966) 
such partisan expression, the state must either balance its views with those of opposing sides, or open the forum or the state's resources to alternative views. This requirement of government neutrality, or at least evenhandedness, comports with Bonner-Lyons' application of the Mosley doctrine when the government is the speaker. The requirement makes clear that the first amendment and the equal protection clause may be violated by a state actor that engages in partisan speech while refusing to grant others a right to reply.

\section{The Variant Public Forum Doctrine and Utility Bill Inserts: A Constitutionally Mandated Right to Reply}

The public forum doctrine as applied to nontraditional forums $\mathrm{m}$ dicates that utility company mailing practices violate the first amendment, unless the utility affords a right to reply. First, the company utilizes a pervasive, effective channel of communication similar to Bonner-Lyons' student message program. Second, the company favors its own statements by precluding others from using its forum. The utility thus violates its Mosley obligations not to favor one side of a controversial issue and to afford all pomts of view an equal opportunity to be heard.

The fact that the favoring (and favored) party is a utility, rather than an immediate office of the government, does not excuse the application of Mosley obhigations. As set out in Part III, the utility's mailing practices constitute state action. The utility must, therefore, be regarded as the state for the purposes of a first amendment analysis of its mailing practices. When the utility is properly viewed as a state actor, and a state speaker, first amendment principles require that the utility open up its state created monopoly fornm to opposing viewpoints.

A right to reply is not constitutionally mandated when the utility inserts only inforinational statements in its billing envelopes. The cases preclude governmental actors only from engaging in partisan advocacy. Infornnational speech or a "fair presentation of facts" is permissible, but the state inay not bestow an unfair advantage upon a particular speaker.

The question then becomes where to draw the line between information and propaganda. The FCC has devised a practical standard for broadcasters which could be einployed in a similar fashion to determime when public utilities' statements trigger a right to reply. The FCC

(control by government of political propaganda); Yudof, When Governments Speak, 57 TEx. L. REV. 863 (1979) (means of limiting government speech). Determining whether the government in fact is speaking or whether a particular governmeut official is expressing his or lier own views in an individual capacity may be difficult, however, and may present constitutional problems with respect to the imdividual's biberty of expression. Kamenshine, supra, at 1116-19. 
requires broadcasters to provide fair and balanced coverage of those themes that are deemed "controversial issues of public importance"197 and has set forth guidelines to aid in the determmation of whether particular topics raise these fairness responsibilities. ${ }^{198}$

If the FCC distmction were applied to the mailing practices of utilities, utilities would still be entitled to present information on noncontroversial topics, without an obligation to accomodate replies. Utility bill inserts relating to controversial topics would be beyond the state actor's legitimate scope of untempered speech, ${ }^{199}$ however, so the utility would have to permit a reply. Nuclear power has already been interpreted as a controversial issue by the $\mathrm{FCC}{ }^{200}$ Utilities, therefore, must allow replies to statements, such as the one that prompted the Con Ed case, advocating the development of nuclear power. If the company would prefer to avoid having to allow replies, it may simply cease making controversial statements in the billing envelopes; but when the utility opens its billing envelopes to present its own views, it automatically opens those envelopes to opposing stateinents.

This distinction between controversial or partisan speech and informational speech provides the broadest possible latitude for entities to present information that is not controversial, while carefully scrutinizing areas with a potential for abuse. To permit utilities to engage in partisan speech would encourage propaganda and governmentally approved imdoctrimation of the public. The purpose of the first amendment, however, is to ensure the free flow of information in order to act as a check on government. The state's role is a negative one: to ensure the functioning of the marketplace of ideas. Thus, a utility's attempt to sway public opimion through advocacy is more offensive to the first amendment than is government's discrimination in favor of a particular party. It presents a twofold evil: not only would the government ignore its constitutional role as the guarantor of the unimpeded media of expression, but the first amendment would also fail in its role as a check on the power of government. Absent a right to reply, the state would in essence act simultaneously as both censor and propagandist.

197. The Handling of Public Issues Under the Fairness Doctrine and the Public Interest Standards of the Communications Act-Fairness Report, 48 F.C.C.2d 1, 10 (1974).

198. "Public inportance" is determined by a subjective evaluation of the impact that the issue is hikely to have on the community at large. Id. at 12. To determine if a topic is "controversial" necessitates measuring "the degree of attention paid to an issue by governmont officials, community leaders, and the media." Id. Robert D. Kamenshine suggests a tcst employing solely the "public importance" rubric. Kamenshine, supra note 196, at 1114-15.

199. An analogous situation exists for private nonconumercial broadcasting stations that are funded through the government's Corporation for Pubhic Broadcasting. Such stations are prohibited from editorializing and supporting or opposing any candidate for political office. 47 U.S.C. $\S 399$ (a) (1976). The constitutionahity of this law appears questionable following Con Ed.

200. Saginaw Valley Nuclear Study Group, 41 F.C.C.2d 606, 607 (I973). 


\section{ADDRESSING CRITICISMS OF THE RIGHT TO REPLY}

Part V anticipates and addresses some of the likely criticisms of the proposed right to reply to utility bill inserts. Specifically, this Part maintams that the "chilling effect" and "right not to speak" arguments against a right to reply do not withstand analysis. It also discusses feasibility problems of a right to reply, concluding that there are sufficient analogues available to enable courts to apply the proposal without undue difficulty.

\section{A. The Utilities' First Amendment Arguments}

Utility coinpanies will likely argue that even if the first amendment supports a right to reply, such rephes would violate the utilities' paramount first amendment rights. One likely first amendnient arguinent that the utilities may raise against the right to reply is that such a right will violate the utilities' first amendment rights by "chilling" their ability to express their views on both pohitical issues and other topics of interest to the public. A similar concern was expressed by the Supreme Court in Miami Herald Publishing Co. v. Tornillo ${ }^{201}$ with regard to the print media.

In Tornillo, the plamtiff, a political candidate, wanted to enforce a statute that granted him a right to reply to a newspaper's attack. The Supreme Court feared that such a right would have placed a "penalty" on editors in terms of printing, composing, and materials costs and would have taken up space which could have been devoted to other material which editors may have preferred. In an effort to free themselves from this penalty, editors might decide to avoid controversy entirely, thereby blunting or reducing political and electoral coverage. The government enforced right to reply would result, in the Court's view, in a dampening of the vigor and limitation on the variety of public debate. ${ }^{202}$ Since the journalistic coverage of pohitical debate is central to the political process, the Court stated that it was uncertain whether government regulation of a newspaper's editorial process could ever be implemented in a manner consistent with the first amendment. ${ }^{203}$

The Tornillo analysis, however, is not applicable in the case of a utility's mailing practices. The print media has historically been granted an independence from government that does not extend to other information sources, not even other menibers of the communica-

201. 418 U.S. 241 (1974).

202. Id. at 257.

203. Id. at 258 . 
tions industry such as the television and radio broadcasters in Red Lion. In Red Lion, the Court implied that the broadcast media is not entitled to the same independence from government as are newspapers; the broadcast media could be forced to air responses to personal attacks and political editorials. ${ }^{204}$ Utilities are more akin to broadcasters than to newspapers in terms of public accountability and regulatory scrutiny. In fact, the utilities are far more entwined with government than were the broadcasters in Red Lion. Moreover, since utilities are not engaged in the busmess of informing the public, as are the media, the policy concerns that require media independence froin government (so that the inedia can perform their job of informing the public and guarding against governmental abuse), do not apply to utilities. Rather, the opposite is required; state regulation is needed to ensure that the utilities serve the public interest and to keep utilities from using their governmental authority for improper ends.

It is of course possible that a utility's political speech will be restrained by a right to reply for opponents. Any chilling effect on utilities' ability to engage in controversial political speech, however, would not curtail their ability to inform the public on proper nonpolitical topics such as conservation inethods and the desirability of avoiding peak use-hours. Such inessages would not mandate a right to reply since they present information ratler than opinion. ${ }^{205} \mathrm{~A}$ utility may avoid affordmg replies in billing envelopes by avoiding political activism in its envelopes. Moreover, a utility has open to it all the traditional theaters of expression, sucli as newspapers, if it feels stifled by opposing replies. Thus, any chill on a utility's speech is not significant enough to freeze out the first amendment rights of those who seek to reply and those who wish to receive the reply.

In addition to making a "chilling effect" argument, a utility may argue that a right to reply would violate its first amendment right to refrain from being forced to speak out in favor of viewpoints that it does not espouse. Sucl a "right not to speak" was recognized in Wooley v. Maynard, ${ }^{206}$ where the Supreme Court found unconstitutional a New Hampshire statute whicli imposed criminal sanctions on persons who obscured the state's notto "Live Free or Die" embossed on automobile license plates. The Court held that such a statute denied the plaintiff's first amendment right to refrain from advocating an ideological view that he found unacceptable. ${ }^{207}$

204. See supra text accompanying notes $65-76$.

205. See supra text accompanying notes $197-200$.

206. 430 U.S. 705 (1977). See also Abood v. Detroit Bd. of Educ., 431 U.S. 209 (1977) (compelled contribution to support an ideological cause held unconstitutional); West Virginia State Bd. of Educ. v. Barnette, 319 U.S. 624 (1943) (compulsory flag salute held unconstitutional).

207. 430 U.S. at 714-17. 
The right not to speak argument is inapposite, however, for much the same reason as the chilling effect argument failed. Utilities need not open their billing envelopes to political issues. Unlike the plaintiff in Wooley, utilities have the option of not speaking at all. Once having done so, however, they may not claim that a responsive statement violates their right to keep the forum free from opposing views. To do so represents an unconstitutional discrimination on the basis of content. Moreover, a utility's speech is not impaired by a reply, since any danger of the public confusing the reply with the utility's own speech inay be avoided by including a statement that the utility does not endorse the opposing view. ${ }^{208}$

\section{B. Implementing the Right to Reply}

A number of impleinentation issues arise concerning the right to reply, ${ }^{209}$ including which individuals or groups should be allowed to voice their opposing views; who should make this decision; and who will pay for the cost of reply. There is precedent in analogous contexts which suggests ineans of solving these probleuns and deunonstrates the feasibility of allowing responsive inserts. Three possible systems present themselves for enabling viewpoints opposing the utility to be heard: (1) all possible views could be presented in the forum; (2) regulatory agencies could exercise oversight in determining which groups would be representative for countering utilities' speech; or (3) the utilities could be given direct responsibility for ensuring that alternative viewpoints are expressed, that is, they could present the opposing side themselves. There is an analogue for each of these possible solutions in current law.

First, SEC rule $14 \mathrm{a}-8$, requiring corporate directors to include shareholders' proposals in proxy solicitations, ${ }^{210}$ presents an analogous situation. If the company opposes any shareholder proposal, it must also, at the proponent's request, include in its proxy materials a statement of up to 200 words by the proponent in support of the proposal. ${ }^{211}$ Management, which acts as a fiduciary, may not monopolize the proxy mechanism or preclude qualifying statements from being expressed through its foruin.

The proxy regulations provide a workable inodel for implementmg a right to reply.public utility bill statements. Utility coinpanies, as

208. Cf. PruneYard Shopping Center v. Robins, 447 U.S. 74, 87 (1980) (shopping center unay post signs to disavow endorseinent of expression).

209. Many of the inplementation problens actually argue more in favor of an absolute ban on political statements in billing envelopes than against replies as sucl. The option of a ban was, however, foreclosed by Con Ed.

210. 17 C.F.R. $\$ 240.14 a-8$ (1981).

211. Id. $\S 240.14 \mathrm{a}-8(\mathrm{~b})$. 
regulated monopolies, act as quasi-fiduciaries for their ratepayers. Thus, any qualifymg ratepayer would have the right to present his or her views in the utility's forum. Instead of limiting each statement to a fixed limit of 200 words as in shareholder proposals, the equal protection clause's proscription of discrimination on the basis of viewpoint may require utilities to allow opponents of utilities' statements the right to present responses equal in length to the stateinents that prompted them. If proposals were "substantially duplicative" of one previously submitted by another proponent, however, these statements, like duphcative proposals in the proxy solicitations context, ${ }^{212}$ would not be required to be mcluded with the utility's stateinents.

Second, each state's utility regulatory agency could be given authority to determine which organizations are representative of opposing views and then permit these organizations to respond to utilities' statements. If more than one organization is deeined responsible and representative, the agency could enable these groups to take turns responding. Such a systein would not constitute a state abridgement of speech simce the agency would not exercise editorial discretion over the content of statements, but would only determine which groups had the right to speak. The analogue here is section 315 of the Cominunications Act of 1934. ${ }^{213}$ That section requires broadcasters which permit legally qualified candidates for public office to use a broadcasting station to afford equal opportunities to all other candidates for that office. The right is more limited than the SEC's proxy regulations that require manageinent to include all non-duplicative shareholder statements. Rather, the right extends only to those who have been determined to be appropriate recipients of a right to reply. In the same way, regulatory agencies could screen applicants to determine who shall be permitted to express opposing views in bill envelopes. Such a selection could be made on a first-come first served basis, by lot, or in rotation from a group of qualified representatives of the public. Although such a selection may be difficult given the state's obligation not to discriminate among speakers, ${ }^{214}$ the proposal is not unworkable given the fact that the state could make selections in a way which was not discriminatory, but random or sequential.

Finally, the broadcast industry's fairness doctrime suggests another way of implementing a right to reply. The fairness doctrime imposes a variety of obligations on broadcasters to cover issues of public importance and to present them in a balanced fashion. ${ }^{215}$ Specifically, broad-

212. Id. § 240.14a-8(c)(11).

213. 47 U.S.C. \& 315 (1976).

214. Mosley, 408 U.S. at 102.

215. 1949 Report on Editorializing by Broadcast Licensees, 13 F.C.C. 1246 (1949). 
casters must give adequate coverage to public issues, ${ }^{216}$ and coverage must be fair in accurately reflecting opposing views. ${ }^{217}$ If sponsorship is unavailable, the broadcaster must fulfill its obligations at its own expense. ${ }^{218}$ Such a system would grant utilities greater control over their billing mechanism, smce they would be able to select speakers, yet would impose accompanying financial costs upon thein. The system avoids the potential problem of the quantity of requested responses exceeding the scarce space limitations in billing envelopes. Since the utility is a state actor, however, allowing it to select speakers poses the same proponent selection difficulty under the first amendment as was expressed in the second analogue. ${ }^{219}$

Although each of the above analogues suggest a possible methodology for enabling the presentation of opposing viewpoints, the inethodology for determining who shall speak in a utility's forum is not of the essence. Utilities may even be able to select respondents randomly by lot, ${ }^{220}$ so long as the choice were not made on the basis of content or viewpomt in violation of Mosley. Any system which enabled opposing views to be heard through the forum would substantially coinply with the obhigations of the first amendment and the equal protection clause. The crucial issue is that alternative views be voiced so that the utility cannot monopolize a umiquely effective medium. A right to reply does not require the utility itself to present the opposing opinions, with its potential for abuse, nor does it obligate the utility to disceru the nature of public opinion. It does, however, enable the public to have a more direct voice in the operation of its quasi-public corporations, possibly granting ratepayers the ability to hold utilities to a higher level of public accountability.

In each of the three above analogous situations the question of who will pay the costs of responses has not prevented the presentation of opposing views. In each situation, the question has been resolved by regulatory agencies or Congress, either by charging speakers reasonable sums in order to respond ${ }^{221}$ or by obliging broadcasters to provide

216. United Broadcasting Co., 10 F.C.C. 515 (1945).

217. New Broadcasting Co., 6 RAD. REG. (P \& F) 258, 259 (1950).

218. Cullman Broadcasting Co., 25 RAD. REG. (P \& F) 895 (1963). See Red Lion, 395 U.S. at 377. The FCC has determined that nuclear power is a controversial issue of public importance and that, therefore, under the fairness doctrine broadcasters must afford a reasonable opportunity for the presentation of contrasting views. Saginaw Valley Nuclear Study Group, 41 F.C.C.2d 606, 607 (1973).

219. See supra note 214 and accoinpanying text.

220. The Alaska Supreme Court has noted that random deletions made due to space limitations of a forum may be made without constitutional violation. Alaska Gay Coalition, 578 P.2d at 960.

221. See 47 U.S.C. $§ 315(b)$ (1976); 47 C.F.R. $\$ 14 a-8$ (1981). 
alternative views at their own expense. 222 In general, as a matter of fairness, whenever the shareholders of a utility pay the costs of the statement, respondents should also be required to pay; but, when a utility receives a subsidy from the ratepayers through reduced costs, opposing views should also get a free ride.

Developing a methodology for affording a right of reply burdens regulatory agencies with the problein of utility partisan speech. Still, such agencies have expertise im contending with problems in overseeing inonopohistic industries. The coinplexities of the problem do not argue in favor of shirking the obligation to provide for response, but instead suggest the need for well reasoned and effective means of guaranteeing the public the right to express opposing views to a utility's partisan stateinents.

\section{CONCLUSION}

Courts should recognize that the public forun doctrine of the first amendment requires state-like entities such as utilities to afford opposing groups a right to reply in billing envelopes whenever such entities use billing envelopes to voice their opinion on controversial issues. This right to reply is appropriate given the policies of the first annendinent, is feasible in light of the three analogues in similar reply situations, and is a fair burden to place on utilities in exchange for the inonopolistic benefits bestowed upon thein by the state.

Bruce W. Blakely*

222. See supra note 218.

* A.B. 1978, Stanford University; J.D. 1982, Boalt Hall School of Law, University of California, Berkeley. 